Portland State University

PDXScholar

Winter 2016

\title{
The Making of Seaside's "Indian Place": Contested and Enduring Native Spaces on the Nineteenth Century Oregon Coast
}

Douglas Deur

Portland State University, deur@pdx.edu

Follow this and additional works at: https://pdxscholar.library.pdx.edu/anth_fac

Part of the Archaeological Anthropology Commons, and the Social and Cultural Anthropology Commons

Let us know how access to this document benefits you.

Citation Details

Douglas Deur. (2016). The Making of Seaside's "Indian Place": Contested and Enduring Native Spaces on the Nineteenth Century Oregon Coast. Oregon Historical Quarterly, 117(4), 536-573.

This Article is brought to you for free and open access. It has been accepted for inclusion in Anthropology Faculty Publications and Presentations by an authorized administrator of PDXScholar. Please contact us if we can make this document more accessible: pdxscholar@pdx.edu. 


\title{
The Making of Seaside's "Indian Place"
}

\author{
Contested and Enduring Native Spaces \\ on the Nineteenth Century Oregon Coast
}

THE CLATSOPS AND THE CHINOOKS occupied a unique pivot-point on the region's historical landscape. Linked by kinship ties, and both speaking dialects of the same Chinookan language, the Clatsop and their villages lined the south bank of the Columbia River estuary while the Chinooks and their villages lined the north. From those homelands, these tribes dominated social and economic life at the mouth of the river through the early Northwest fur-trade era, as they had for countless generations prior. Oregon history is replete with references to their cultural prominence, their remarkable affluence and trading skill, and their devastating demise in the wake of epidemic disease. Yet this familiar story is incomplete. Despite significant disruptions, these Native communities continued to survive, physically and culturally. They also sustained a modicum of community life within their homeland, survivors adapting to change as they coalesced into ethnically segregated enclaves on the margins of non-Native settlement. The late nineteenth century proved an especially pivotal time, when Clatsop and Chinook communities established new homes away from the Columbia tidewater and peripheral positions within an emerging social order dominated by non-Native interests.

During the mid nineteenth century, non-Native settlement and military facilities reshaped the Columbia tidewater. Bombardment by the Hudson's Bay Company, epidemic disease, and military fortifications tore out the demographic heart of the Clatsop people, largely displacing them from permanent settlements on the Columbia River estuary's south shore. While many Clatsops evacuated northward across the Columbia, the far southern end of the Clatsop homelands, in today's Seaside, provided many displaced families with a comparatively isolated and secure stronghold. This area 


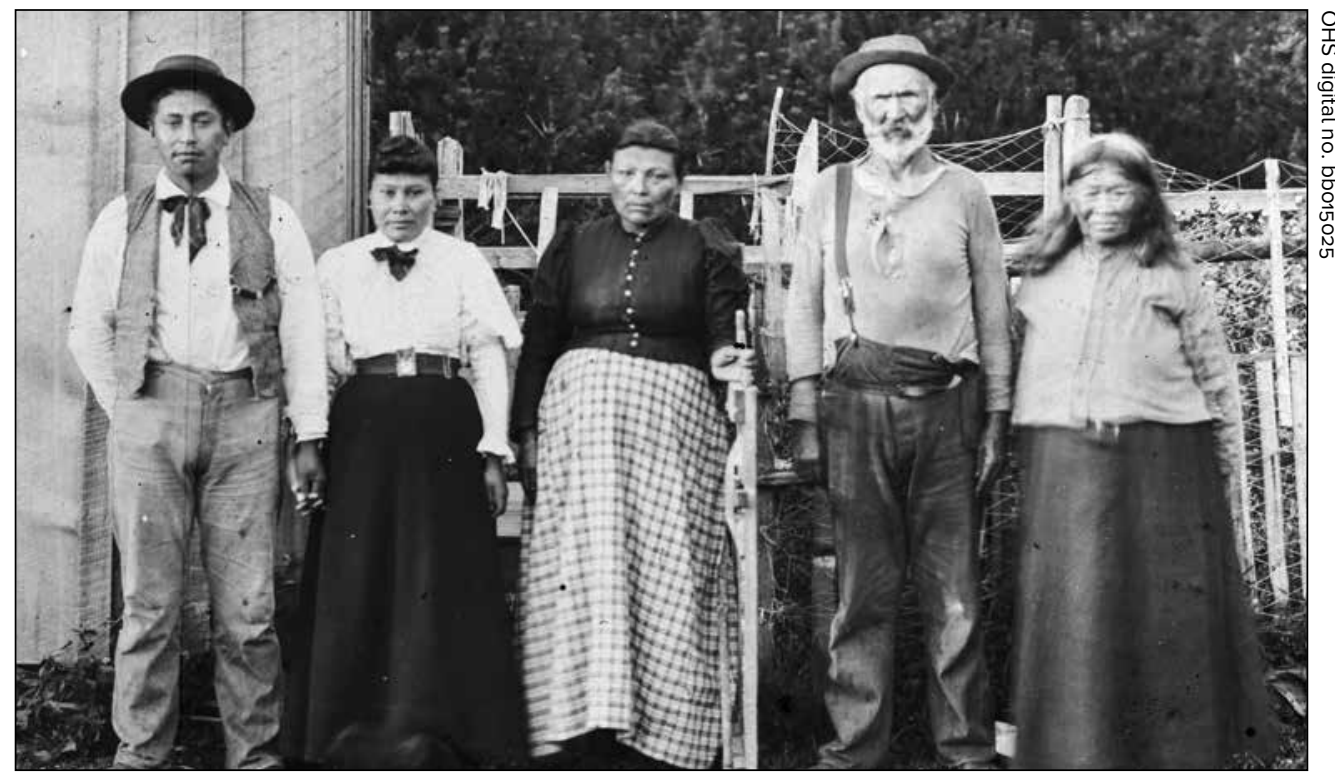

INDIAN PLACE RESIDENTS (from left to right) Joseph Swahaw, Grace (Kotata) Swahaw, Jennie Lane, Michel Martineau, and Jennie Michel are pictured here in an undated photograph. Indian Place families hailed from numerous villages displaced by Euro-American settlement in the mid to late nineteenth century. Forging new lives in Seaside, they played pivotal roles in that town's early non-Native community and economy. By the early twentieth century, many moved north or south to join other tribal communities on the Oregon and Washington coasts.

housed tribal settlements of great antiquity, their locations shifting over millennia in response to the shoreline's changing configuration. ' During the late nineteenth and early twentieth centuries, Seaside, Oregon, was home to the last major tribal community remaining in Clatsop traditional territory serving as an important refuge for displaced families seeking distance from pressures to the north. Called Seaside's "Indian Place" by non-Native settlers, and ultimately by tribal members themselves, this community remained a sanctuary in a once rich and uncontested tribal territory. It was one of a small network of remaining, interconnected tribal settlements ranging from Bay Center, Washington, to Garibaldi, Oregon - longstanding villages that took on new significance, where marginalized Clatsops, Chinooks, Tillamooks, and others could persist, regroup, and adapt to the changing circumstances of the period. The living gathered with the remains of the dead in this enclave, affording modest protection from the apocalyptic changes that so radically disrupted tribal lands, lives, and worldviews. Although the conditions were absolutely not of the tribal community's choosing, residents of the Indian 
Place exerted autonomy and creativity in their dealings with the non-Native world, allowing for their survival into modern times. Even as the nineteenthcentury Indian Place site now lies submerged beneath the pavement and vacation homes of Seaside, its inhabitants' descendants play active roles in the cultural traditions and political life of modern tribes.

Seaside's Indian Place, like many other tribal communities of the late nineteenth and early twentieth centuries, was a "transitional community" - a place where people regrouped in the wake of an apocalyptic moment in their history, significantly realigned their social and economic relationships, and moved on with firmer footing and a better understanding of how to engage the non-Native world. For those Northwest tribes not formally placed on reservations in the nineteenth century, such transitional communities were important, if not always final, destinations. In redefining Native American life for two or more generations, these communities represented a key intermediate step in the rapid transformation from pre-contact lifeways to modern tribes and tribal governments. ${ }^{2}$ Visited by anthropologists, tourists, and other recorders, these places became conduits of cultural knowledge into modern times and were among the primary venues for Indian-white encounters in the late nineteenth and early twentieth centuries. This article illuminates this dimension of Northwest tribal history through the experiences of displaced tribal families at the Indian Place. Without an appreciation of the role of such villages in the history of displacement from the Columbia River estuary, one cannot understand how Native American peoples of the contact period on the north Oregon coast successfully endured, becoming part of today's tribes and tribal confederations.

\section{FROM CONTACT TO DIASPORA}

In 1792, when Robert Gray successfully navigated the Columbia River bar and traded with Chinookan-speaking peoples along the river that would be named for his ship, the Columbia Rediviva, the Clatsop homeland lined the ocean beaches and Columbia River estuary, encompassing a significant portion of what is today Clatsop County, Oregon. While written accounts vary in detail regarding the identity and location of individual villages, historical and ethnographic sources generally agree that Clatsop settlement centered around two hubs on the northwest and southwest corners of their territory. By far, the predominant core of Clatsop settlement consisted of a group of large villages centered on Point Adams, a windswept sandspit projecting into the ocean mouth of the Columbia River in what is today Fort Stevens State Park. This was arguably among the largest Native American settlement complexes in today's Oregon. Among the most prominent of the villages was Niák'ilaki, the "pounded salmon place," a village name also 


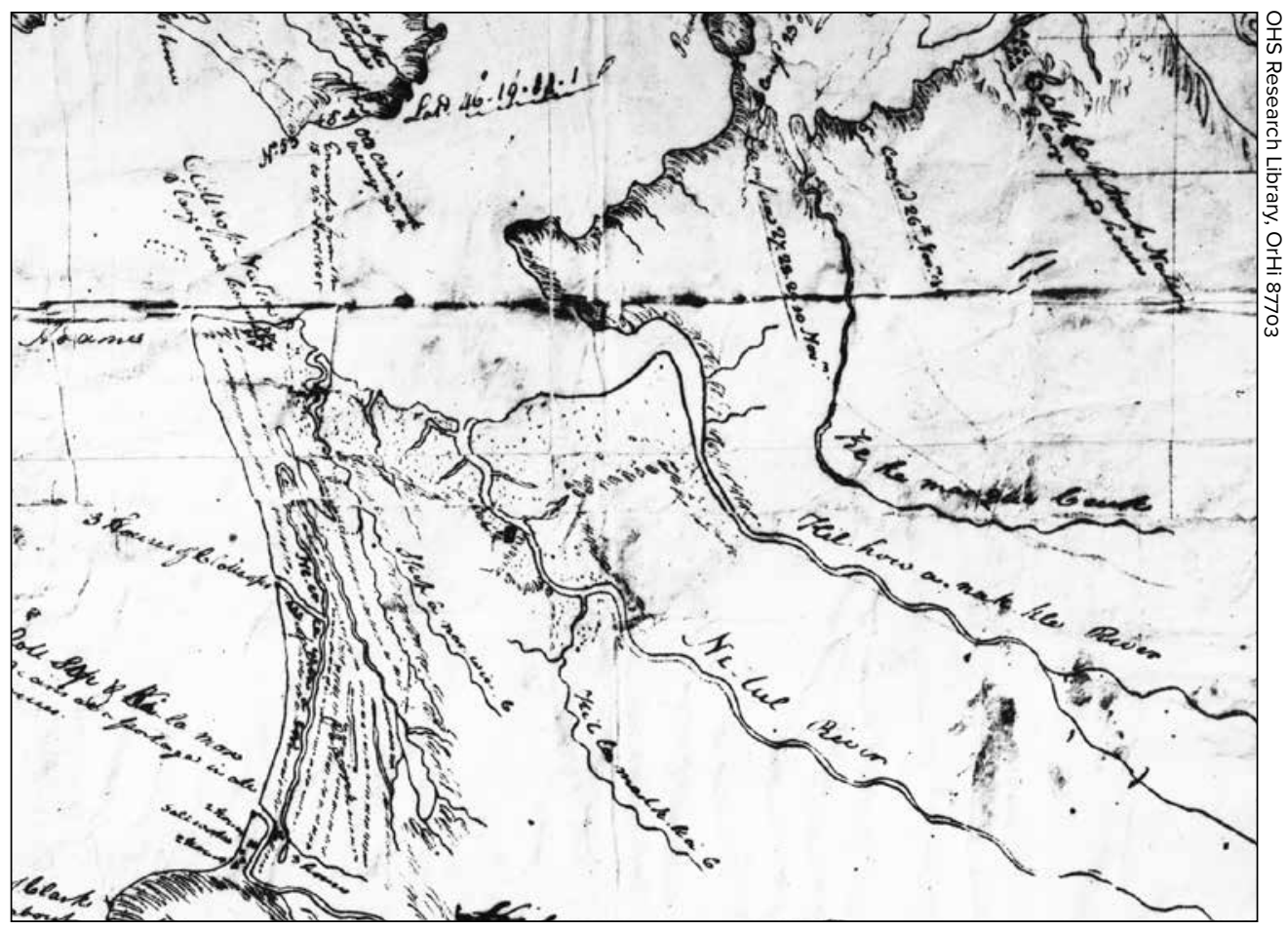

THIS DETAIL OF MERIWETHER LEWIS AND WILLIAM CLARK'S 1806 map shows the Columbia River and Pacific coast. Pictured in the northwest quadrant of the map is the premier Clatsop village on Point Adams, Neak'ilaki - a "Clott Sopp Nation" village of "8 large wood houses." Sitting at the Columbia River mouth, the Clatsop retained this site in their unratified 1851 treaty, only to see it occupied by the military Fort Stevens. To the south, Lewis and Clark mapped seven houses of "Clott Sopp and Ki la mox" - a precursor of the community that would become Seaside's "Indian Place."

glossed as tät'cap (pounded salmon) - the origin of the name Clatsop, later applied to the people and to the county named in their honor. ${ }^{3}$ The other, much smaller group of Clatsop settlements was centered roughly fifteen miles to the south on the tidewater shoreline of today's Seaside, where the Necanicum estuary and its tributary creeks, the Neawanna and Neacoxie, converge (see map above). ${ }^{4}$

Much earlier than most of the Pacific Northwest, the Clatsop homeland became contested terrain. European and American ships grew in presence on the Columbia River after Gray's arrival, carrying out a bustling exchange with Native traders in furs of sea otter, beaver, and other species. Transported to China, the furs commanded great prices - the foundation of sprawling international trade networks contingent on Native hunting and trading skills. 


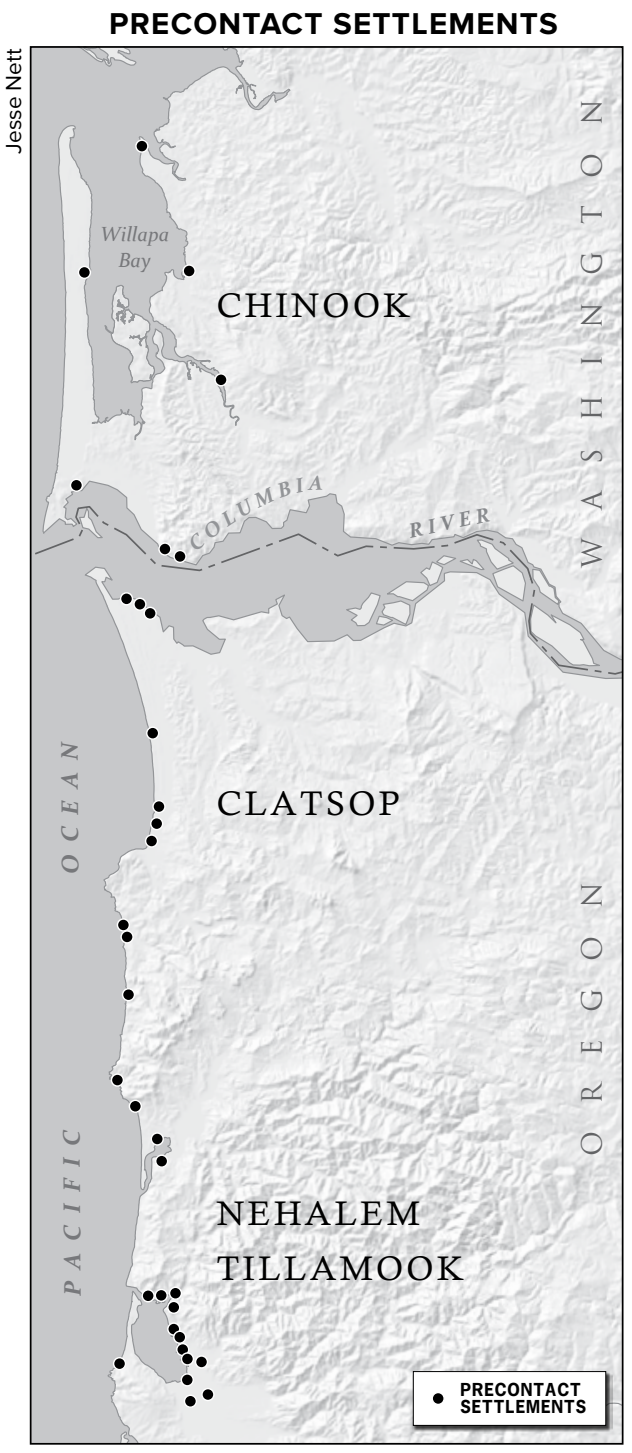

NON-RESERVATION TRIBAL COMMUNITIES

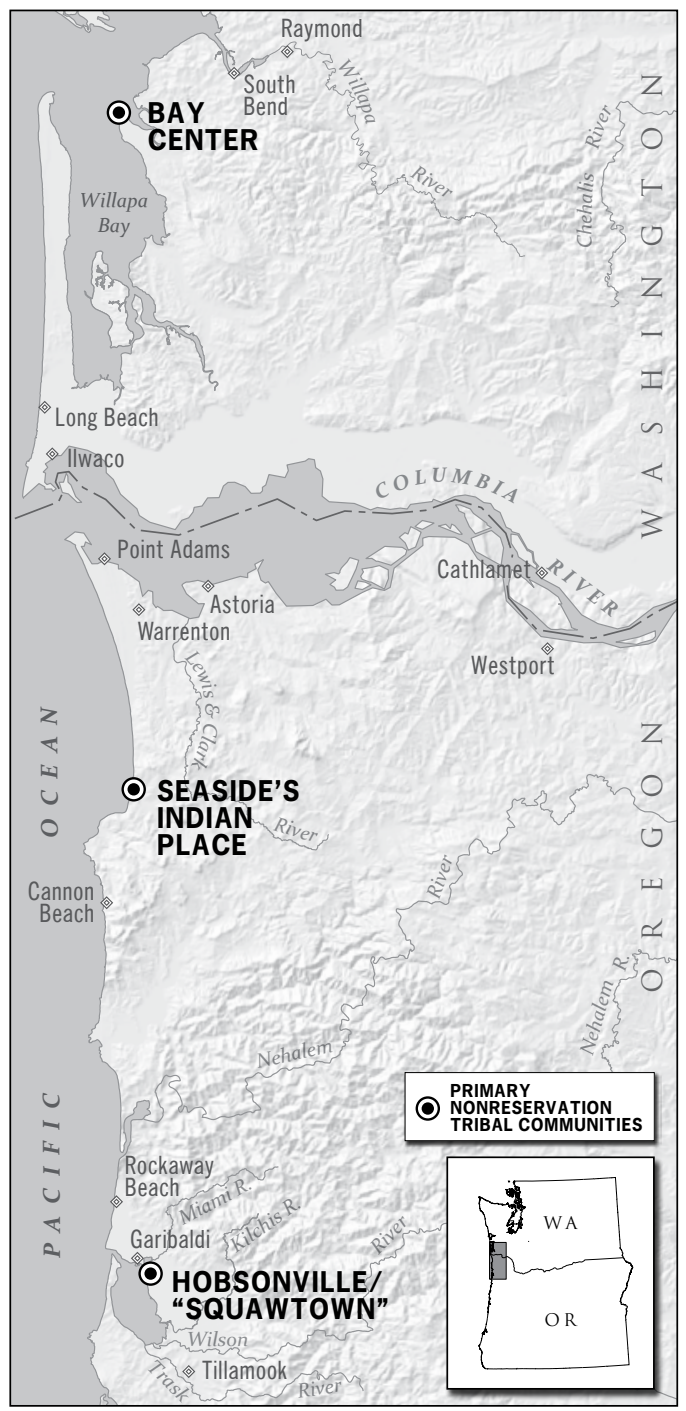

KEY SETTLEMENTS of Clatsop, Chinook proper (“Lower Chinook”), and Nehalem-Tillamook are pictured here on the eve of European settlement (left) and in the late nineteenth century (right). The map on the left shows a vast constellation of precontact settlements on the coasts of northwest Oregon and southwest Washington. Chinook and Clatsop settlements are based on "Chinookan Peoples of the Lower Columbia," Oregon Historical Quarterly (Spring 2016), and Nehalem-Tillamook settlements are based on Nehalem Tillamook: An Ethnography (2003). The map on the right shows principal non-reservation tribal settlements of the late nineteenth century. While these maps are not comprehensive representations of tribal population in each period, they suggest the effects of nineteenth century displacement and demographic contraction. 
The 1811 arrival of the Astor Party and the construction of their fort on Clatsop traditional lands marked the first emergence of a permanent and land-based non-Native community in the Northwest. The land-based fur trade coalesced around the fort built at modern-day Astoria and was reoccupied, in succession, by the North West (1813-1821) and Hudson's Bay companies (1821-1848). Non-Native settlement soon began to expand from this foothold, reaching into the rolling hills of the Clatsop Plains, where some of the Northwest's earliest agricultural settlements tentatively took form on the sandy and rain-leached coastal soils.

For a brief time, Native economies and societies flourished amidst the expanding and increasingly multiethnic trade networks centered on the lower Columbia fur trade. Chiefly figures loomed large, their domains encompassing prime sea otter and beaver habitats and, more significantly, the intersection of preexisting Native trade networks along the coast and far into the interior. Famously, this allowed the enterprising Chinook leader Concomly to consolidate political and economic power to a level arguably unprecedented among lower Columbia River tribes. Interethnic relations on the fur-trade frontier remained remarkably peaceful and collaborative for a time, supported by mutual economic interests as well as extensive marriage between women of the Chinook, Clatsop, and other river tribes and men of the Astoria fort - strategic marriages promoted by tribal and fur company leaders alike. By the early 1820 s, the Chinookan-speaking peoples and the Hudson's Bay Company ( $\mathrm{HBC}$ ) together exercised a monopoly over lower-Columbia River trade that could scarcely be disrupted by other tribes or commercial interests. ${ }^{5}$

Still, this was an awkward peace, involving vulnerabilities and contradictions that ultimately brought an end to Native American preeminence along the lower Columbia. If the fur trading companies had economic incentives to bind themselves to lower Columbia tribes, non-Native traders were also hampered by strategic vulnerabilities and dependence on the tribes for necessities from furs to food. While these obstacles had been nominally tolerated by the North West Company, the Anglophone ranks of the HBC - which acquired the Astoria fort and other North West Company assets in 1821 - found them downright menacing. By 1824, the HBC had constructed a new center at Fort Vancouver, far upriver on the arable alluvial shore of the Columbia. This action was in part a response to the rapid extirpation of sea otter on the outer coast and a shift to interior species and trade networks, and also to concerns about food security, tribal economic hegemony, and other misgivings relating to the HBC's many 
dependencies on Chinookan-speaking peoples at the river's mouth. ${ }^{6}$ In spite of the move, these insecurities persisted. Vastly outnumbered, the HBC managers remained concerned about the potential for violent Indian attacks. The 1811 sinking of the Astorians' ship, the Tonquin, by Nuu-chahnulth Native combatants on the west coast of Vancouver Island remained fresh for many years in the minds of many HBC employees, some of whom (including Chief Factor John McLoughlin) had adopted the children and married the widows of those killed in the conflict. ${ }^{\text {Increasingly concerned }}$ that even the perception of vulnerability was a threat to their enterprise, the HBC pursued a strategy of deterrence - what scholars have in more recent times termed a policy of "massive retaliation" - responding swiftly and severely to small interethnic conflicts in the hope of preempting large, more menacing encounters. On rare occasion, HBC employees within the Columbia District sometimes retaliated by attacking or razing entire villages. One such attack occurred at the mouth of the Columbia River and was one of the earliest and most formidable shocks to Clatsop persistence in that core part of their homeland. ${ }^{8}$

In March 1829, the British ship the William and Ann had arrived at the mouth of the Columbia after an extended journey from London, en route to Fort Vancouver. Stranded on a sand bar, the ship was pounded relentlessly by huge waves, ultimately drowning all of the crew members. Clatsops soon gathered up goods that washed ashore from the ship - a traditional prerogative within their territory, reflecting a concept of "property" quite different from that of $\mathrm{HBC}$ managers. On receiving word of the shipwreck, McLoughlin dispatched a gunboat to recover the goods. At this time, rumors surfaced that the Clatsops of Point Adams had killed survivors from the ship and were refusing to return the property. Under McLoughlin's orders, in June, the HBC gunboat commanders sought to make an example of the Clatsop for both the purported violence and the loss of property by shelling the Clatsop village of Niák'ilaki, burning it to the ground. While McLoughlin indicated in official correspondence that four Indians were killed, a detailed and graphic tribal oral tradition suggests that the attack killed many more residents of this village as well as guests from other tribes. Elders of the 1930 recalled the event from the perspectives of neighboring Nehalem-Tillamooks who were visiting the village during the attack:

A sailing ship drifted along this coast. It wrecked and it came ashore. Blankets, food, bread, sugar, rice, poison - everything washed ashore from that ship. ... One boat of white men came to fight. That main white man wanted furs. One Indian, a Nehalem, tried to trade away his beaver skins. Those Clatsops from Point Adams village said "No." 
They prepared to fight. These white men didn't strike first. They landed on shore. The Indians shot at them. Then this ship shot back. They shot a big gun, a cannon. These Indians ran for the brush. The white men came ashore and set fire to the town. They killed people.

They killed an Indian man. His mother and father were killed with the rest. He himself hadn't taken anything from the wreck. He had been visiting the village at Newport when it had come ashore. His young son cut the [child carrier?] strap, freeing himself. The boy ran away on the beach.

The narrative explains that the boy, and perhaps others, retreated to the relative safety of the Seaside villages:

He walked over here to the village at Seaside. His uncles saw him coming. He ran in the water. They asked him, "Where is your father?" He said, "The last I saw of him, two white men were killing him." Then his uncles cried. ${ }^{9}$

The single major interethnic battle of the Columbia estuary, this attack was a foreboding hint of the violence yet to come and of the ultimate displacement of Clatsops from their longstanding stronghold at the river's mouth.

Only later did McLoughlin determine that there was no evidence of Clatsops' murdering the crew of the William and Ann. He was forced to admit to his superiors that "in my opinion none of the crew were murdered" and that rumors to the contrary ostensibly had been fabricated by trade competitors of the Clatsops. ${ }^{10}$ In his letter to the Governor and Committee of the HBC, dated August 13, 1829, McLoughlin offered a broader strategic logic behind the attack:

the Indians considered the [salvaged] property as ours ... if we had not made a demand of it we would have fallen so much in Indians Estimation that whenever an opportunity offered our safety would have been endangered . . . our people [had] no alternative but to attack the Indians and act towards them in the manner they did."

In light of the realpolitik of the Northwestern fur trade, McLoughlin insisted that the violent attack had been a strategic necessity - required to uphold the reputation of the $\mathrm{HBC}$ and, in so doing, forego other, more imposing threats to the security of its employees and property.

The Clatsop quietly sought to rebuild what was left of their village, a few relocating to other villages, with no apparent retaliation against the well-armed HBC. The HBC does not appear to have provided reparations or made notable overtures of peace to their former Clatsop trading partners following the attack, even as the company worked to expand economic and strategic ties to upriver Chinookan-speaking communities in the Portland 
basin. The Clatsop were increasingly peripheral, their economic sway waning within the expanding, HBC-dominated inland trade empire and the evolving economic geographies of the Pacific Northwest. The same economic forces that had fostered a brief and delicate peace at the river's mouth were now undermining tribal security.

Moreover, even by this time, epidemic diseases were taking a steady toll on the Clatsop and neighboring tribes. As traders came from ports in Europe, Asia, the Pacific Islands, and the Americas, a growing succession of diseases - smallpox, influenza, and others - arrived with the growing ship traffic along the bustling Columbia River corridor. Predictably, a series of major epidemics spread through the bustling trading centers at the river's mouth. One of the worst arrived in 1830 , only a year after the HBC attack. The "fever and ague" or "intermittent fever," as it was often called in the journals of the time, was reported at Fort Vancouver in that year - the first major epidemic witnessed directly by non-Indians, probably malaria. ${ }^{12}$ The disease decimated the tribes of the lower Columbia and beyond, radically and permanently changing the demographics of the region as a series of "sicknesses" pulsed through tribal communities - often rebounding in the summers, when mosquitoes rapidly spread disease along the marshy margins of the Columbia. By the time the United States secured its claims to the lower Columbia two decades later, over 90 percent of the Native population had died - the 1830 epidemic arguably being the largest contributing event. ${ }^{13}$ Despite its broad impacts throughout the Far West, the epidemic's effects were most lethal on the densely settled Columbia River tidewater. Few were spared; even Concomly was dead before the disease had run its course. The Clatsop villages at the mouth of the Columbia were among the hardest hit, survivors abandoning some of the smaller and more peripheral settlements to regroup and recuperate with kin at the Point Adams settlements centered at Niák'ilaki. The villages at modern Seaside also began to contract and reorganize. Survivors converged in the larger settlements, redesignating smaller settlements as seasonal camps or impromptu burial grounds.

As American occupation began in the years ahead, the Clatsop experienced rapid textual and legal displacement from their core homeland. Settlers raced into the Clatsop Plains in the late 1840 s, and by the 1850 passage of the Oregon Donation Land Law by Congress (solidifying the act taken by the Oregon Provisional Government in 1843), they were encroaching on the Point Adams Clatsop community. More than a few of those settlers actively intimidated residents in an attempt to eliminate competing claims to the land. Reporting to Oregon Territorial Governor Joseph Lane a few months before the Donation Law's passage, Clatsop sub-agent of Indian Affairs Robert Shortess explained: 
the Indians in this vicinity . . have been told they might as well give up their lands for what they could get, as the soldiers will soon come and kill them or drive them off; that it was in vain for them to oppose the whites for they would have their land in defiance of them... Their property has been and is constantly passing from them ... they are treated as aliens and intruders in their own country. In conversation with one of them a few days since, he asked why are the Americans in such haste to get our lands. It is even so, but a few years more and disease and death will have done their work [and Oregon's Indians] will have dispersed from the face of the earth. Whether our Government is aware of this fact and waiting for its consummation I will not take upon me to say. But I will say that something should be done for the natives immediately. Justice and Honour demand it. ${ }^{14}$

In this context, Anson Dart was appointed the first Superintendent of Indian Affairs for the Oregon Territory - his principal mandate being the negotiation of treaties with western Oregon tribes, to contain them within reservations and clear ceded lands for non-Indian settlement. In July and August 1851, Dart and his staff encamped at Tansy Point, just east of the Point Adams villages - negotiated with the leaders of tribes from the lower Columbia and adjacent outer coast. His "Treaty with the Clatsop" was completed on August 5, 1851, and was signed by Dart and eleven Clatsop Chiefs, including those known as Tostom, Dunkle, Twilch, Washington, and Kotata, who all would later play a critical role in the Seaside settlements. ${ }^{15}$

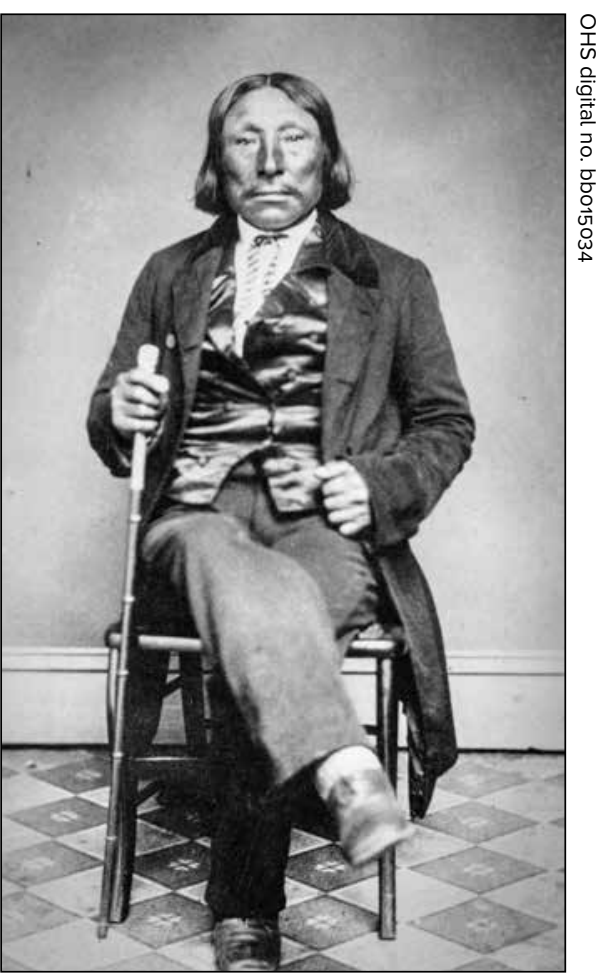

CHIEF TOSTOM, a mid nineteenth century Clatsop leader, is pictured here in an undated studio photograph. Tostum coordinated a peaceful exodus, as the U.S. Army engineers building Fort Stevens expelled Clatsops en masse from their preeminent village at Point Adams. Acknowledging the two persistent cores of Clatsop settlement, the treaty provided for a principal Clatsop reservation at Point Adams as well as a small outlying reservation on the Seaside tidewater, while the remainder of the Clatsop territory was to be ceded for non-Indian settlement. The following summer, the treaty was brought before Congress, where it encountered stiff opposition from Secretary of the Interior Alexander 
H.H. Stuart, Oregon Territorial Delegate Joseph Lane, and others..$^{16} \mathrm{~A}$ coalition of treaty opponents - some hoping to remove all Indians to east of the Cascade Range - was able to have this and other treaties negotiated by Dart tabled by August 1852, and they were never ratified. Forced relocation was tabled, too, by territorial legislators hoping to retain the Clatsops and other Columbia estuary tribes as a source of cheap labor in support of fledgling frontier industries. ${ }^{17}$

Lacking formal legal protections, the Clatsop foothold on Point Adams was growing ever more precarious. Sitting at the Columbia River's outlet, with commanding views of both river and sea, a growing number of non-Indian visitors foresaw the site's strategic importance. From the beginning of the fur trade, British traders had recognized the strategic importance of the point, as had British spies, Warre and Vavasour, who proposed a Point Adams stronghold in a possible war against America in the run-up to the Oregon Treaty of 1846; U.S. Army engineers also viewed the point with much interest as they began planning harbor defenses as American power was consolidated..$^{18}$ Even as the Tansy Point treaties were being signed, international boundaries with British North America (now Canada) remained malleable, and HBC employees, with disputed loyalties, continued to reside in the Oregon Territory. In this uncertain context, President Millard Fillmore approved a proposal by Secretary of War Charles M. Conrad and a "joint committee for the examination of the Pacific coast," calling for the development of military forts at the mouth of the Columbia River. In addition to Cape Disappointment, Washington, the forts would encompass "Point Adams, at the southern side of the mouth of the Columbia River, to include all the land lying within one and a half miles of the northernmost part of the point." 19 Fillmore replied with an internal memo that was remarkable only for its brevity: "Approved February 26, 1852."20 It is unclear whether Conrad and his committee were aware that the Clatsop had reserved this land in the treaty negotiations only a few months before. Regardless, in one hasty proclamation, the Clatsops' claim to the very core of their homeland was effectively extinguished. As settlers and military personnel informed the Clatsop that their treaty afforded no protection, many Point Adams families, perhaps for the first time, began openly exploring options for permanent relocation to off-river communities on both sides of the Columbia River. The Oregon Superintendent of Indian Affairs assigned inexperienced, ad hoc Indian Agents from the community of American settlers - Robert Shortess, and later, W.W. Raymond - to keep the peace and maintain some semblance of federal control and surveillance within a sizeable tribal community slated for eventual removal. ${ }^{21}$

The region's remoteness, however, continued to stall appropriations for fort development, even as local, territorial, and national authorities issued 
stern warnings regarding the military risks of an undefended Columbia River - as U.S. Secretary of War John B. Floyd observed, "our whole littoral frontier is without a gun for its defense."22 Ten years elapsed before Congress approved a bill in 1862 , setting aside $\$ 100,000$ for Columbia River defenses as part of a nationwide effort to fortify undefended coastlines. The Civil War, well underway by that time, intensified congressional interests in Northwestern defense in the way that a few straggling British loyalists could not. Work began by 1863 , with Capt. George Elliott overseeing construction of the "Fort at Cape Disappointment" (later renamed Fort Canby) and the "Fort at Point Adams" (later renamed Fort Stevens). In spite of HBC attacks and epidemic diseases, the Point Adams village had persisted and even served as a refuge for people displaced from other villages, remaining one of the largest tribal communities on the Oregon coast. By the time Elliott initiated construction of the fort earthworks, there were still an estimated 160 permanent residents of the remaining village at Point Adams, a population that swelled to many times that number during multitribal gatherings and peak salmon fishing on the Columbia. Decades later, Native elders recalled the bustling Point Adams village on the eve of fort construction: "[they] used to go there and have a big time and all go but 'the fort got that!'" ${ }^{23}$ Although Clatsop people had reserved the lands of Point Adams in their unratified treaty over a decade earlier (and oral tradition hints that the tribe may have understood the land to be secured despite congressional inaction), federal authorities now demanded their complete removal from the point. ${ }^{24}$ The Army Corps of Engineers pressured the Clatsops to abandon their remaining settlement as well as the adjacent burial grounds, resource harvest areas, and other places of traditional importance within the new military reservation. Elliott negotiated with village headman Chief Tostom, who had been raised at Point Adams and resided there in 1851, when he signed the Tansey Point treaty reserving those lands for the Clatsops. After initial resistance, the Clatsops relented, agreeing to move off the increasingly contested Columbia riverfront to some distance upstream on the Skipanon River near present-day Warrenton. In truth, non-Indian settlers were already encroaching on the fort site, and the Army engineers had to expel those settlers, too; it is likely that land claimants may have, in time, had a similar effect on the Point Adams village complex. In the end, Elliott wrote an open letter of endorsement of Tostom, praising his peaceful oversight of the tribe's forced removal in spite of the fact that he, the "chief of the Clatsop Indians," had "lived for many years at Point Adams, and his ancestors, his children and many of his tribe are buried here." 25

Various impacts on the Clatsop community at Point Adams had come in rapid succession, but the dispossession of their principal remaining settle- 
ment was a sudden and decisive blow. With the loss of Point Adams, the Clatsop homeland instantaneously lost its core, and the larger part of the tribe's population was spontaneously set adrift. The Clatsop people entered a long and painful period of transition. Many, and in time most, would choose to leave for other places. Tostom and his people at first continued to live and harvest resources near the margins of the fort, yet this community dissolved rapidly as the fort grew. ${ }^{26}$ Displaced Clatsops moved north and south in search of alternative homes. The Columbia riverfront and arable

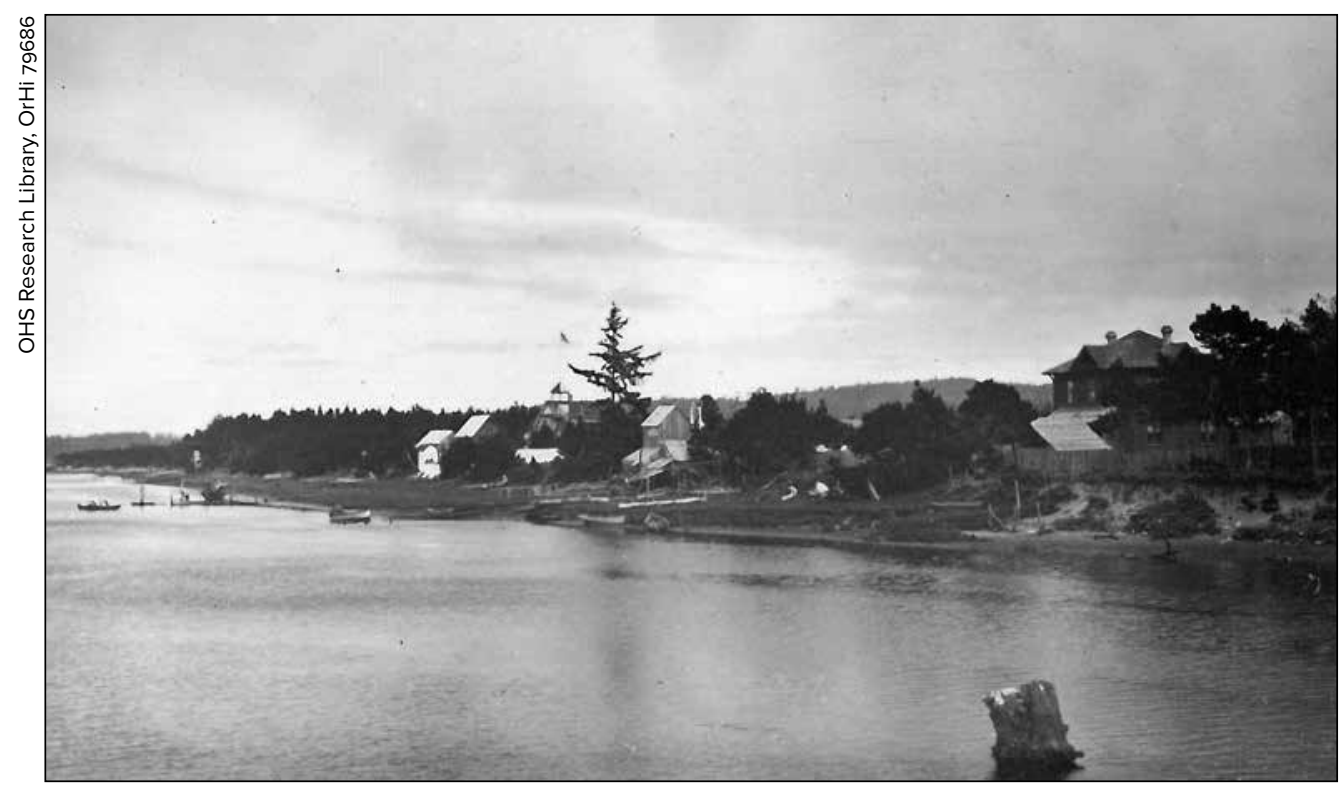

BY THE LATE NINETEENTH CENTURY, the waterfront homes of non-Native Seaside residents and the vacation "cottages" of Portland's leisure class encroached on the Indian Place - still standing in the relatively forested background of this photograph of Necanicum Creek at Seaside in 1899.

Clatsop Plains had been almost fully resettled by this time, leaving few options anywhere near the tidewater. As Oregon Indian Superintendent A.B. Meacham observed: "White men have actually crowded them [the Clatsops] on to the beach of the ocean, not leaving them country enough for grazing purposes for the few horses they possess." ${ }^{27}$ Yet, at least for a time, the sand dunes and beaches in places such as Seaside afforded one of a few refuges to Clatsops displaced from colonized spaces - perhaps the only such suitable refuges within their traditional territory. Thus, as one 
Warrenton settler observed, the displaced tribal community dispersed with astonishing speed, declining "to just a handful by 1870," with most having "moved either North to Washington Territory or South to Necotat village at Seaside." ${ }^{28}$ Holding neither treaty nor land title, the Clatsops increasingly became refugees on their own land, living in tribal enclaves on the margins of non-Native settlement.

In choosing the location of such enclaves, displaced people had no option but to occupy places not preempted by non-Native settlement. They sought places of enduring significance, long used and occupied by their ancestors and their extended families. Many abruptly moved northward, joining Chinook kin centered at Willapa Bay, Washington, where they were increasingly woven into the social fabric of the Chinook tribe along with other displaced Chinookan-speakers from upstream along the Columbia. Some of these, in time, made a secondary, sometimes temporary, move to the federally protected reservation at Quinault - a reservation originally created to accommodate all tribes fronting Washington's outer Pacific coast. Many others moved south. Some joined the Nehalem-Tillamook at the so-called "Squawtown" settlement on Tillamook Bay's waterfront near Garibaldi, and some eventually found their way to multitribal reservation communities even farther afield, in places such as Grand Ronde and Siletz. ${ }^{29}$ Yet, for a time, the Seaside villages were key destinations, remaining the primary resettlement sites within Clatsop territory proper and among the most accessible and inviting places for families displaced from Point Adams.

\section{SEASIDE AND THE “INDIAN PLACE”}

While smaller than their Columbia River counterparts, the villages of the Seaside area had long been consequential, with their inhabitants linked in myriad ways to their northern Clatsop kin. These southern villages were consistently, though often parenthetically, mentioned in early historical accounts. Especially noteworthy were the large year-round village at the Necanicum River outlet commonly called Necotat, and the village and fishing stations together known as Neacoxie, situated less than a mile to the north of Necotat, where Neacoxie Creek exits into the Necanicum estuary. William Clark's journals described the Corp of Discovery's visit to what was apparently Necotat, a lively and congenial community he described as containing three or four longhouses, housing twelve families of "Clatsop and Killamox" close to the mouth of the Necanicum River. ${ }^{30}$ Other nineteenth-century narratives make clear that many non-resident Clatsops from Columbia estuary villages were familiar with the Seaside community - relocating to these southern villages seasonally for resource harvests and social gatherings, especially timed to 
coincide with autumn fishing of coho salmon. Missionaries Daniel Lee and Joseph Frost visited the site often in the late 1830 s and 1840 s, and reported that the mouth of Neacoxie Creek was the "fall salmon" fishery, where one found "the Clatsop Indians waiting for the commencement of their second salmon season, the season on the Columbia having closed in August." ${ }^{31}$

These villages also hosted families from tribes other than Clatsop during these social and subsistence events. As Clark's narrative and other nineteenth-century accounts attest, the village complex was effectively multitribal at that time, with Clatsop and Nehalem-Tillamook both being residents. As Ellen Center, a Nehalem-Tillamook woman from Tillamook Bay, recalled of these villages:

Lots of times I heard the old people speak of the Necanicum River. That was a place where the Clatsop and Nehalem - all people around here - would come together to hunt and fish. The wives would get berries. They were friends, great friends, always visiting, playing games. ${ }^{32}$

Their polyglot population served as the nucleus of an extended kin network reaching north and south from the Seaside area, its members converging seasonally on the Necanicum estuary.

Like most Native settlements in the region, these villages had been exposed to the horrors of epidemic disease, from smallpox to influenza to malaria. Vast burial grounds described in early accounts of Seaside including a single plot, "nearly an acre of this land ... almost covered with human bones and skulls" - may attest to both the scale of the pre-epidemic villages and the abrupt shocks from epidemic diseases on the eve of direct European contact. ${ }^{33}$ Like many Oregon coast villages that survived into the early twentieth century, those at Seaside were places where survivors from multiple villages banded together, probably augmenting their polyglot character and linkages to survivor communities up and down the coast, from Chinooks on the Washington side of the Columbia to Oregon coast Tillamooks and beyond. ${ }^{34}$

If the Seaside area endured as a venue for multitribal gatherings into the mid nineteenth century, it also continued to serve as a place of refuge. As implied by the account of the William and Ann incident, people sometimes retreated to the Seaside villages to escape extraordinary dangers and intrusions at the Columbia River mouth - even well before the HBC attack. Interviewed in 1900, Clatsop elder Jennie Michel recalled oral tradition suggesting that many Clatsops from the Columbia River villages retreated to Seaside on Lewis and Clark's arrival, evading detection from members of the Corps of Discovery, whose approach by land was both unprecedented and unsettling: 
When Lewis and Clark first came and camped on Tongue Point, the Indians believed they came to make war on them and they cut trees across the rivers near their town so the women and children could run to the woods and hide, and came down to the Neahcoxie to the Necanicum and hid their canoes. ${ }^{35}$

In the wake of their forced displacement from Point Adams, the character of the Seaside-area villages as a place of refuge took on new relevance and urgency for the Clatsop. From the time of the William and Ann incident until their forced removal to make way for the Fort Stevens military reservation - a period of only three and a half decades - Clatsop society had experienced a sequence

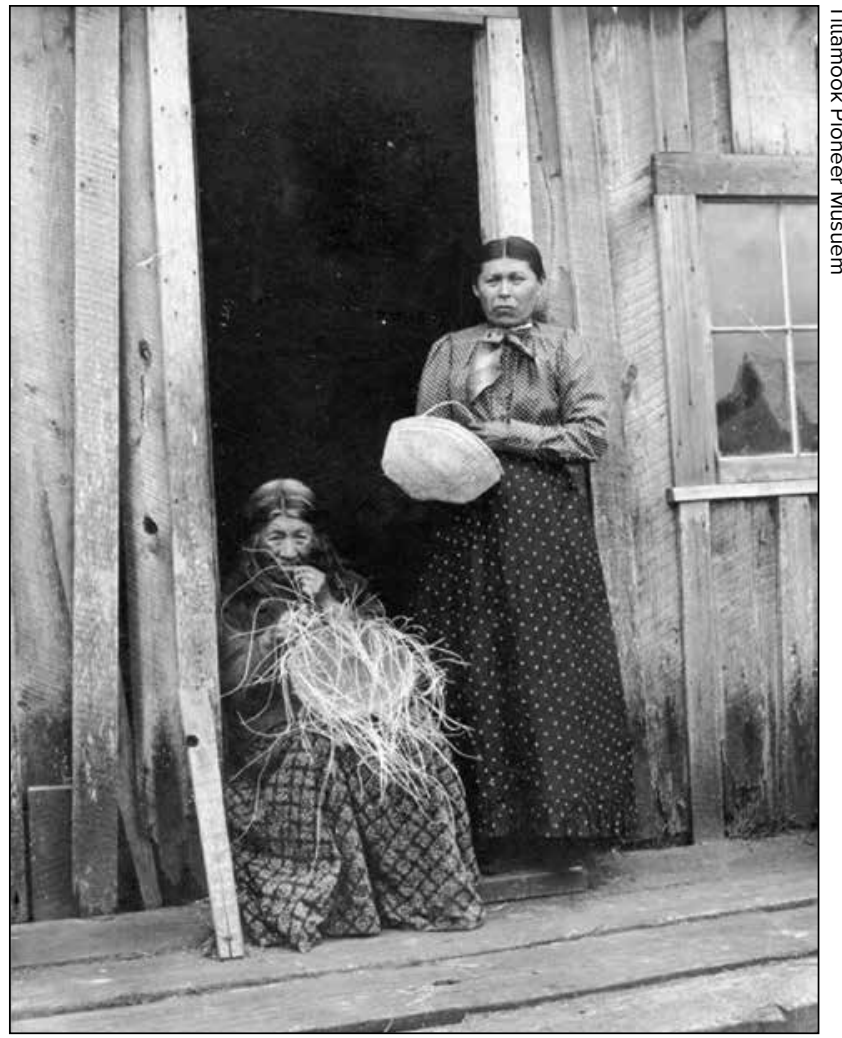

JENNIE MICHEL AND LIZZIE ADAMS (Tsin-is-tum and Ágakalhz) hold baskets made for sale at the Indian Place. A matriarch of the Hobsonville Indian community, Adams was also a skilled basketmaker but lacked a comparable tourist market near her home. Such opportunities enticed her and her family to visit Seaside in the late nineteenth century, making extended stays with relatives who lived there full-time.

of shocks that swept them from their Columbia

River shoreline and threatened to eliminate them as a people. In response, Clatsop families took refuge in communities off the river to regroup and carve out new lives. The use of Seaside as a refuge settlement was a logical, if ultimately tenuous, outcome of deeper cultural practices that had sustained Clatsops for generations prior to the fall of Niák'ilaki, and would for at least a few generations to follow.

During the mid nineteenth century, the Neacoxie settlement just to the north of the "Indian Place" - so long a venue for multi-village gatherings that included Point Adams Clatsops - continued to serve as a refuge of sorts for 
tribal members from the Columbia River villages seeking to avoid Euro-American encroachments. Reflecting the place's function as a locus of tribal social life and resource use, the Clatsop headmen present at the 1851 Tansy Point treaty negotiations had sought and, it seemed for a time, secured permanent access to the fishing stations at Neacoxie as part of the treaty text. Article 2

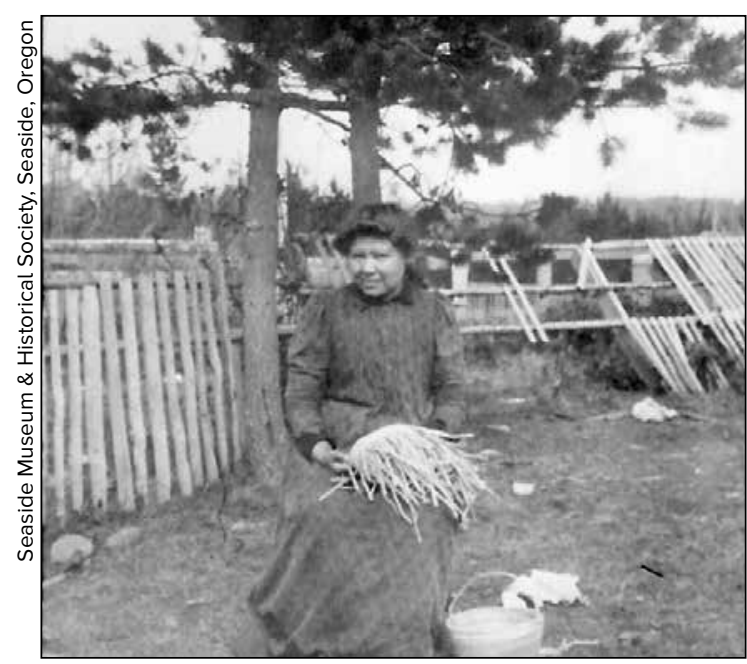

A DAUGHTER OF CHIEF KOTATA, identified as either Filly or Grace Kotata, is pictured here with a partially woven basket. Chief Kotata, his wife De-o-so, and his children were prominent in most aspects of Indian Place community life until the village disbanded in the early twentieth century. Kotata's descendants moved to Native American communities elsewhere on the Oregon and Washington coasts. of their treaty dictated that Point Adams would become the site of the Clatsop reservation, and Article 3 allowed for unimpeded access along the beach from that reservation to the fall fishing stations in the Seaside area, as well as continued fishing rights at that site. ${ }^{36}$ While suggesting the critical, if somewhat secondary, importance of the Seaside area to the Clatsop people, the treaty's unratified status rendered the rights implied within it null and void. As at Point Adams, community life continued at the Neacoxie village unabated through the mid nineteenth century, even as the stonewalled treaty process in Washington, D.C., effectively eliminated tribal title to land beneath the villagers' feet.

For a time, Neacoxie remained not only an important settlement but also a place where missionaries and other visitors congregated when traveling through the area. ${ }^{37}$ When missionary Solomon Smith and his wife Celiast - a daughter of Clatsop Chief Coboway - married in the 1830s, they chose to build a new home not at Celiast's original home on the Columbia River estuary but in Neacoxie village. Even after relocating to assist in missionary efforts, the Smiths continued to maintain a seasonal home at Seaside, famously hosting early settlers, missionaries, and travelers as they passed through Neacoxie village. As J.K. Munford summarized: "When Rev. Frost arrived on the Clatsop Plains on Sept. 1, 1840, he found the Smiths on the 'Neacoxy' in the vicinity of present Gearhart, where they had 'laid up the body of a log-cabin.' Frost liked a more central location 
on the Plains for building the mission, on what was to become known as Smith Lake about a mile north of here. The Smiths agreed to move to that location." The Neacoxie community slowly faded, however, being abandoned for other locations by the late nineteenth century while still being reoccupied as a seasonal fish and shellfish camp well into the twentieth century.

Necotat, meanwhile, grew in importance and remained a major settlement through the late nineteenth century, while remaining somewhat more isolated from the movements of non-Native visitors to this coast. In time, the village of Necotat became a final foothold of village life in Clatsop territory, a place where Native American residents and refugees coalesced into a single community - widely known as the Indian Place - and where the fundamentals of village life endured the longest within Clatsop County. At least two chiefs - Kotata and Dunkle - moved to the Indian Place, transplanting some of the chiefly lineages of the Columbia estuary to this southern outpost. Both were descendants of other chiefs and chiefly families of the contact period and had been signatories to the 1851 treaties - the Clatsop treaty in Kotata's case, both Clatsop and Nehalem treaties in Dunkle's. Accordingly, the Indian Place became a prominent nineteenth-century hub of social, ceremonial, and economic activity linked to an increasingly diffuse constellation of displaced tribal refugees.

The importance of the Indian Place was enhanced by its geographically intermediate position between the two other principal refugee settlements of the area, at Bay Center and Garibaldi, and it became an important stopover point between those two communities. Families moved back and forth between these settlements during the late nineteenth and early twentieth centuries. Social visits were commonplace, and marriages between the families were numerous. As the J.K. Gill family, who purchased lands adjacent to the Indian Place, recalled, "this village in our first years here was quite a stopover for Indians traveling from Tillamook to Bay Center, Wash[ington]."38 Like the area villages reported by Lewis and Clark generations before, the Seaside settlement was a community of combined Clatsop and NehalemTillamook descent and, in truth, may have begun to self-identify more as Nehalem than Clatsop. By the time anthropologist Franz Boas visited the Indian Place in 1890, "they had all adopted the Nehelim language, a dialect of the Salishan Tillamook [due to] frequent intermarriages with the Nehelim." Residents directed Boas to the Bay Center Chinooks in search of the few remaining fluent speakers of Clatsop. Only some three decades after their forced displacement from Point Adams, the last significant enclave of fluent Clatsop speakers was no longer situated within Clatsop traditional territory, but in the lands of the Chinooks. ${ }^{39}$ 


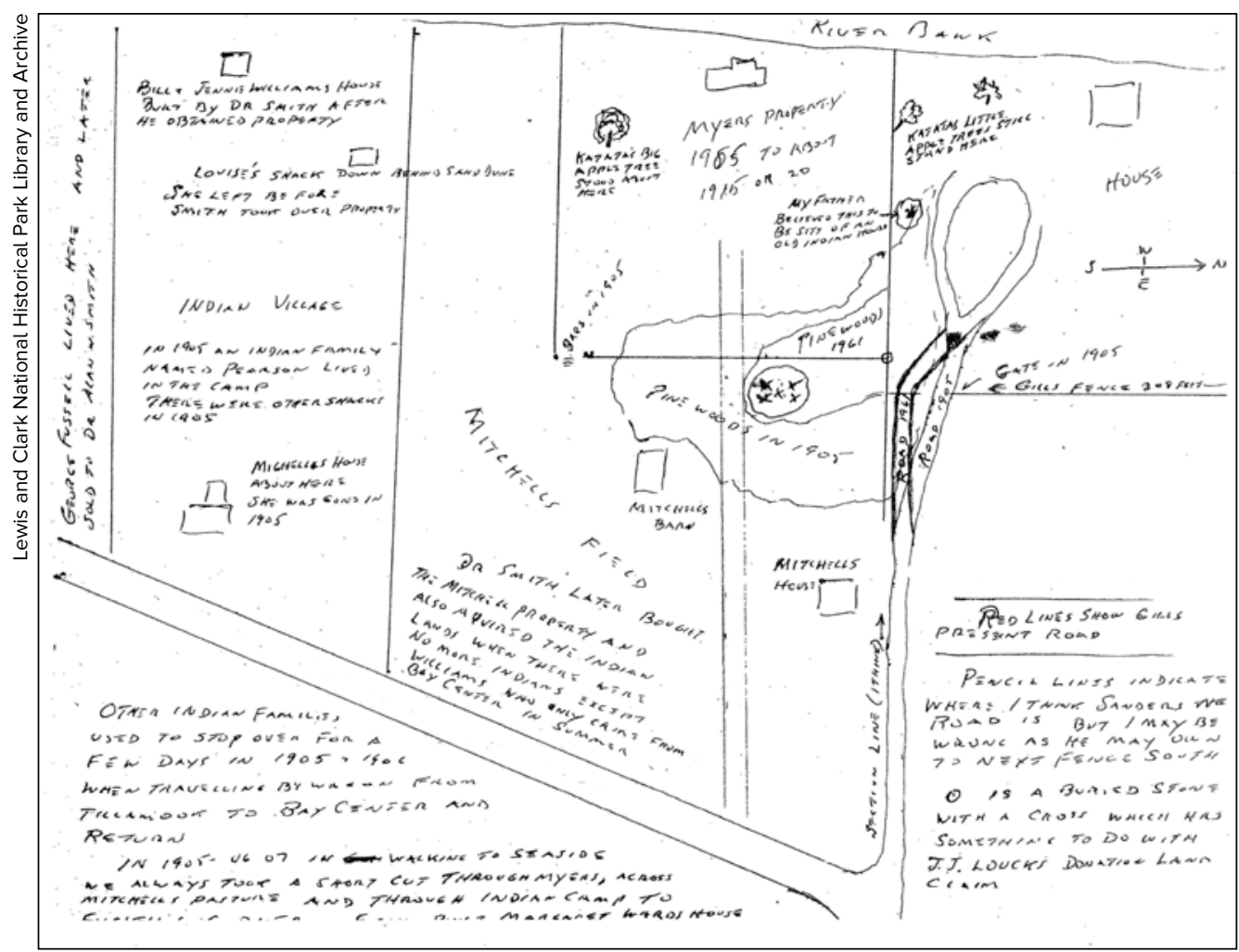

HAROLD GILL, owner of J.K. Gill stores in Portland, created this hand-drawn map of Seaside's Indian Place in 1961 based on recollections of the village as it existed in the late nineteenth and early twentieth centuries. Clearly visible are references to the homes of the Michel ("Michelle" or "Mitchell") Williams, the Pearson families, and "Louise" (probably Lousia Wyaleta) as well as apple trees planted by Chief Kotata and other landmarks. Margin notes mention continued use of the site by the Williams family and others traveling between the villages that persisted at Hobsonville and Bay City. Sensitive information regarding grave sites has been removed for this publication.

Living tribal members were not the only ones to relocate to the Indian Place. Displaced Clatsops also moved their ancestors' remains from village burials on the Clatsop Plains and beyond. In the wake of white settlers' reoccupation, disturbances of burials were widespread on the rapidly transformed landscape. Canoe burials were often scuttled, looted for grave goods or the canoes themselves, which were sometimes taken by settlers for impromptu river crossings. In some cases, burial sites' human remains were burned or tilled to clear the land and apparently to alkalize the leached sandy soil as a planting medium for new crops. ${ }^{\circ}$ The people who moved to the Indian 
Place brought human remains from less protected villages so they could be buried and monitored. Oral traditions refer, for example, to a village near Warrenton that had housed many refugees shortly after their displacement from Point Adams:

They say they gathered up most of the bodies and took them down to by where they were living in Seaside... some of the settlers up here saw that happening ... the Indians didn't talk about it much, they just did it. ${ }^{41}$

Another account mentions displaced Point Adams residents likewise exhuming and relocating burials from the Garibaldi area. ${ }^{42}$ Residents of the Indian Place also abandoned traditional burial practices such as canoe or tree burials in favor of relatively protected subterranean burials and burial cairns. Writing in the twentieth century, area resident Pauline Jorgenson recalled:

After the white people came here they buried their dead under ground. Most every thing belonging to the dead person was put under ground with the corpse. If he had a horse it was killed and put on top of the grave. ${ }^{43}$

Only through such unprecedented precautions, undertaken within view of remnant villages, were graves made secure. Yet, as the land beneath the villages and gravesites was not held by Native people in title, even these strongholds remained precarious.

In time, the Clatsop residents of the Indian Place were able to secure title to the land. Situated within a Donation Land Claim (DLC) registered to James Cook, the village lay outside the area Cook worked to "prove up," as required by the law. By 1870, Cook sold a portion of his claim, including the Indian Place, to W.J. Loomis, who in turn sold portions to T.B. Morrison. In 1879, Morrison subdivided the land and sold the active village site to resident couple Jennie Michel and Michel Martineau. Morrison also sold adjacent, smaller tracts to other individuals, including many Clatsop descendants, such as the Lattie family, the children and grandchildren of an HBC fur-trapper patriarch and a Clatsop matriarch, who had established but then sold the first DLC in the Seaside area. ${ }^{44}$ Together, these private land holdings became a de facto reserve created and owned by tribal members seeking to maintain a small community on what had been, until very recently, their uncontested lands. Eleven years later, Native families living on Tillamook Bay purchased their own enclave near Garibaldi under the leadership of Chief Illga Adams - an action that was perhaps inspired by the Seaside example; ultimately, that land provided an alternative foothold for some Seaside tribal families as non-Native settlement gradually enveloped their community. The Oregon Superintendent of Indian Affairs occasionally dispatched agents from Siletz and Grand Ronde to assess the condition of these unaffiliated north coast 
tribal settlements, and the agencies assigned to those tribes bore intermittent, nominal responsibility for the oversight of unenrolled, off-reservation Indians. Still, these connections were transitory, the agents having more pressing demands on the reservations and limited legal authority beyond the reservation boundaries. ${ }^{45}$

From this small foothold, the Indian Place community remained an enduring hub of tribal life in the rapidly reoccupied territories of the Clatsop through the late nineteenth and early twentieth centuries. Population numbers are elusive but seem to have fluctuated widely as people came and went; indeed, the community's very dynamism was key to its success, allowing families a residential foothold even as circumstances required that they travel broadly for both traditional pursuits and new economic activities. The community's attentions were focused at once inwardly and outwardly; families regrouped and reorganized traditional social life in this vital community in creative ways, and navigated new relationships with the emerging non-Native community and tourist economy of Seaside. Over the course of about a half century, from roughly the 1860s through the 1910 s and beyond, the Indian Place increasingly served as a locus of cross-cultural exchange, where Native people forged new relationships and new identities relative to the non-Native world. As an enduring Native enclave on the margins of a growing tourist community, the Indian Place stood apart. Celebrated basket-makers, canoe-builders, and storytellers assembled in the village, their traditional skills taking on new meanings in the rapidly changing social milieu of early Seaside. As recalled by Clatsop Plains resident Jim Brougher:

[They] lived at what we called the "Indian place," on the bank of the Necanicum.... They were experts in weaving baskets and making dugout canoes. They made baskets that were displayed at the World's Fair in 1906. I have some of those baskets which were purchased by my mother and father. I was also able to obtain a dugout canoe that was reputed to be the last one ever made by the Clatsop [in that period]. ${ }^{46}$

Women were notably successful in eking out a living in the new economic order. They sold baskets to tourists, sold berries and clams to the Seaside House and other inns, and worked as domestic staff at those establishments. Interethnic relationships were not always congenial, and economic relationships were often exploitative. Nonetheless, the Indian Place residents were able to exert agency in their dealings with the non-Native community and to manifest longstanding cultural values in new and adaptive ways - redefining Native identity in a way that continues to shape tribal life into the present day. 
Early in the history of non-Native settlement at Seaside, the Native community's facility in procuring wild foods gave the Indian Place both influence and inroads with their new neighbors. Fledgling non-Native farms often struggled to supply the food needs of Seaside, and wild foods harvested by Indian Place residents - especially on the Necanicum River estuary - were sometimes essential to the sustenance of the non-Native community and to some of the earliest resorts in Seaside, including rail magnate Ben Holladay's ostentatious Seaside House - the origin of both the tourist economy and the name of today's Seaside, Oregon. ${ }^{47}$ Founded in 1871, the Seaside House was the area's first resort and the foundation of all north coast tourism that followed. As local settler and historian Inez Hanson noted, "some of the food of the Holladay house and of all the white people of the area, was supplied by the Indians." ${ }^{88}$ As traditional berry picking had helped maintain social relationships within and between village communities, so the provision of berries now helped forge important friendships between Native and non-Native families. Hanson continues:

Any of the early residents could remember the Indians appearing at the door with whatever might be in season at the time. They might bring freshly killed meat, clams which had just been dug or some of the wild berries which were so plentiful. [Early settler] Maude West Prescott could vividly remember their having come with wild strawberries which grew in the grass out on the sand ridges. How she loved them, especially with good rich cream from one of the family's cows. These foods, the Indians sometimes wished to sell or trade for some interesting item, but often they were brought simply as gifts from a friend. ${ }^{49}$

As time passed, tribal roles and occupations quickly adapted, keeping pace with rapidly evolving local economies by moving from subsistence tasks to diverse occupations that supported the fledgling tourist industry. More often than not, those occupations continued to draw on traditional skills. Both men and women from the Indian Place gathered clams and caught fish, which were sold to visitors. Later, tribal members sold fish and shellfish to local seafood markets and buyers selling to the Portland market. Firewood gathering, construction, building repairs, and maintenance all became growing parts of men's work in the new hotels and cottages. The occupation for which the Indian Place was most well-known, however, was basket-making. Certain basket makers experienced statewide celebrity.

Available historical accounts identify a number of Indian Place residents by name; a thorough review of their biographies suggest the prominence, skills, and diversity of the little community. Central to the early Indian Place settlement were Clatsop Chief Kotata (d. 1883) and his Tillamook-born wife 


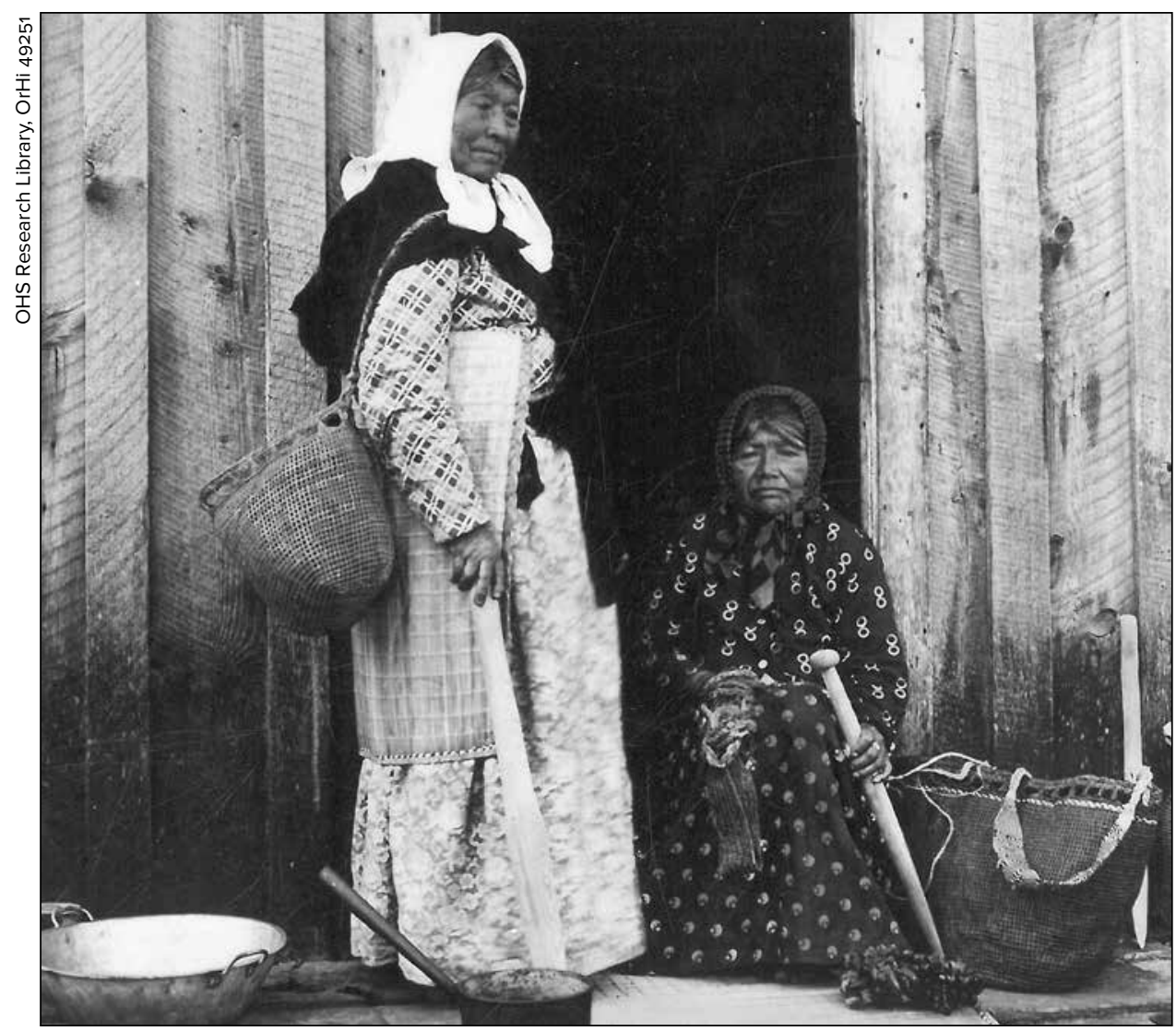

JENNIE MICHEL (TSIN-IS-TUM) AND DE-O-SO are pictured here at Indian Place. Most (but not all) accounts identify the seated woman as De-o-so, a wife of Chief Kotata. Both women hold digging sticks for gathering clams, roots, and other subterranean resources. Large, looseweave baskets allowed easy carrying, washing, and drainage of such goods. Designed for traditional subsistence, the resource harvest toolkit increasingly served double-duty as Indian Place residents dug clams and gathered basket-making materials for the benefit of tourists.

De-o-so. The couple moved to the village at some point during the forced exodus from Point Adams and was instrumental in coordinating some of the northern Clatsop relocation to the Seaside area. A former resident of the Columbia estuary villages, Kotata "knew Lewis and Clark and their men ... hunted elk with them," and was a signatory to the 1851 treaty..$^{\circ} \mathrm{He}$ was described in some sources as "the head man of the Clatsop clan" of the period and a pivotal figure in maintaining peaceful relationships between Oregon settlers and the Clatsop during the many frictions of the nineteenth century. ${ }^{51}$ At the Indian Place, he became a celebrated figure - building a house and 
planting an apple orchard that continued to provide fruit for the community well after his death. ${ }^{52}$ Although details are sparse, Kotata appears to have been a de facto leader of the community, especially during the sixteen years from the Clatsop expulsion from completion of Fort Stevens until his death.

Among the many other people who lived at the Indian Place, none were the focus of such local attention as Kotata's niece, Jennie Michel or Tsin-istum. Michel was born about 1819, although some accounts place her birth date as early as $1814 . .^{53}$ Certainly, she was still a child when her father was killed by the $1829 \mathrm{HBC}$ bombardment of Point Adams. Following the death of her first husband, Nehalem-Tillamook leader Wah-tat-kum, she married Michel Martineau, an HBC employee from the Red River region of Manitoba. The son of a French-Canadian father and a Chippewa mother, Michel Martineau (ca. 1823-1902) was the fireman aboard the HBC steamer ship Beaver, the first such ship to operate on the Columbia, and played a role in the hostage-recovery efforts at the end of the Whitman Incident. Living in the Seaside community from the late nineteenth century until her death in 1905, Michel became a magnet for tourists and was often, erroneously, celebrated as "Last of the Clatsops." She and her husband became the cornerstone of the Indian Place community. They "looked after the community" as modern tribal descendants recall - helping needy members of the community and overseeing the transfer of lands and housing between tribal members coming and going from the Indian Place. ${ }^{54}$ Indeed, there are hints that Tsin-is-tum inherited some of the oversight responsibilities held by her chiefly uncle Kotata and his immediate family prior to his death, only four years after her acquisition of the Indian Place lands from Morrison. The Martineau home became a place of gathering for many tribal members, including residents and those who passed through, heading north or south along the coast.

Tsin-is-tum earned money by digging clams or making baskets for the Seaside and Portland markets. She and her contemporaries were often seen on the tidal flats of the Seaside area, gathering clams or basketry materials. By one local account:

[She] would go out and walk long distances, even in her old age, gathering roots and reeds to use in making her baskets. John Sundquist, Sr. remembered how, when he was young he had watched her passing his home near the mouth of the Wahanna [Neawanna Creek, on the Necanicum estuary] ... one Christmas morning "Mrs. Merchino" came walking past, barefooted, in a layer of snow that had covered the ground during the night. On her head she carried a huge bundle of tiny roots of the spruce and hemlock trees which she had pulled from the bank above, as she walked along the Neacoxie. These, with reeds from the marshes, were the materials that she used in her work. ${ }^{55}$ 


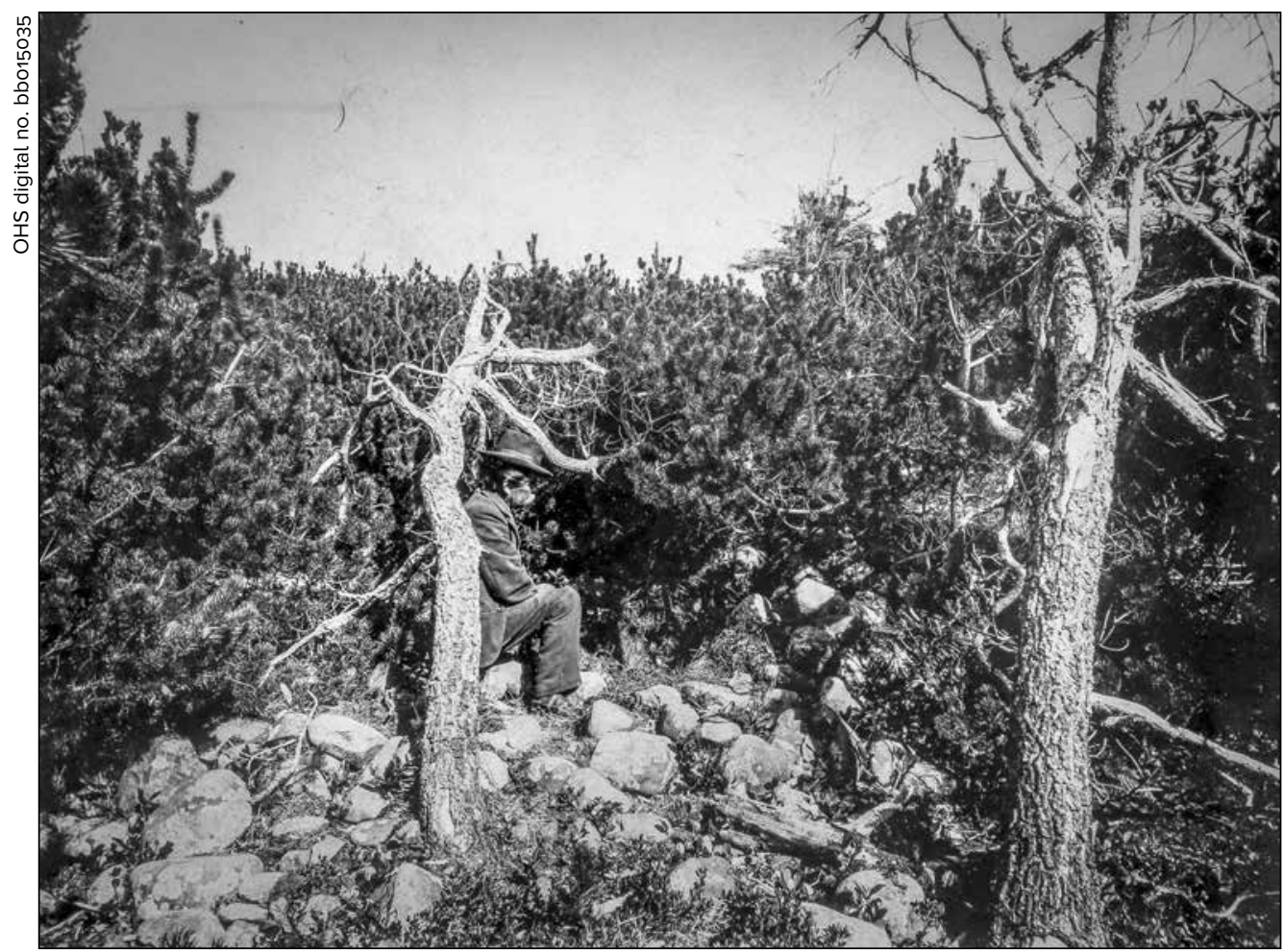

SILAS SMITH is pictured here in 1900 in Seaside, Oregon, at the cairn used by the Lewis and Clark Expedition for salt-making. As part of an Oregon Historical Society investigation, Smith interviewed Jennie Michel (Tsin-is-tum), who identified the location of the cairn based on her mother's recollections. A commemorative park based on her account occupies the site today.

Although Tsin-is-tum listed her occupation simply as "clam digger" in the 1900 census, she was most famously a basket maker. She supported herself by selling baskets to the burgeoning number of tourists and posing for photos with them at the Indian Place, communicating with visitors using a mixture of Chinook Jargon, English, and hand gestures. She made increasingly simple baskets in response to tourists' tastes and kept many of her best baskets hidden from their view. As would be noted in her obituary in the Morning Oregonian, "It is doubtful if any person, man or woman, in the State of Oregon has been photographed so frequently as has Jennie Michel. ... Many a basket did she sell at a fancy price, which was gladly paid for the photograph privilege also." ${ }^{56}$

Tsin-is-tum was also important in the documentation of Clatsop tribal history. In 1900, members of the Oregon Historical Society expedition, led by 
the charismatic Portland attorney Silas Smith recorded her stories - being the son of early settler Solomon Smith and Coboway's daughter Celiast, Smith spoke Clatsop and served as her interpreter. The placement of the Lewis and Clark "salt cairn" monument in Seaside, today managed by the National Park Service, is based on her memories of oral tradition regarding the Corps of Discovery, conveyed to Smith at the time. ${ }^{57}$

There were other accomplished storytellers in the community as well. For a time, Nancy and Edward Gervais lived at the Indian Place. Nish-Slush, or Nancy Gervais, was the daughter of a Nehalem Bay chief - a signer of the 1851 Nehalem treaty - and his Clatsop wife. Edward Gervais (ca. 1836-1909) was the son of Astor Company employee Joseph Gervais and Coboway's daughter Yiamust. Although the family sometimes lived on Nehalem Bay, and was for a short time the only family living in what is today Cannon Beach, they resided at the Indian Place for extended periods during the nineteenth century..$^{58}$ Both Nancy and Edward were hired at the Seaside House. There, they worked in various capacities, but most famously served as hired storytellers for hotel visitors. Through this connection, Nancy became a principal source of the Neahkahnie treasure ship story - an enduring and prominent part of Oregon coastal lore, which she had originally learned from her father. Rooted in a nearly inextricable mixture of historical fact, folklore, and dramatized fiction, and varying in its details, the tale described tribal ancestors' witnessing a ship under siege, its crew burying a chest (and possibly a murdered slave) near modern-day Manzanita. ${ }^{59}$ Prompted by these accounts, treasure-seekers have continued to scour the mountain into recent times, some illegally excavating pits within state park and private lands, apparently without success.

Also residing at the Indian Place was Clara Pearson (née Oskalowis), one of the most famed storytellers and ethnographic consultants in the history of Oregon's north coast. Pearson possessed a detailed memory and openness to working with anthropologists, including Boas students May Mandelbaum and Melville and Elizabeth Derr Jacobs, following her move from Seaside to Hobonsville. Through these connections, Pearson became the sole source for entire volumes devoted to her detailed recollections of Nehalem language and oral tradition. Nehalem-Tillamook Tales and The Nehalem-Tillamook: An Ethnography are based almost solely on Pearson's accounts, and most other published anthropological writings on Nehalem-Tillamook culture are derived significantly from recordings of her stories, songs, and recollections. ${ }^{60}$ Some portion of this corpus of Nehalem oral tradition she learned from her mother, Ellen John Oskalowis, who also lived at the Indian Place into the early twentieth century, and her father, 
Chief Esahtin - a signer of the 1851 Nehalem treaty. Among Clara's circle of friends and neighbors during her time in Seaside was Louisa Wyaleta - also the daughter of a Nehalem chief (Wyaleta), who had signed their 1851 treaty.

Also residing in the village were Clatsop Chief Dunkle - a signatory of the 1851 Clatsop and Nehalem treaties - and his wife Cleocast. They raised their children, Joe Duncan and Mary Duncan Angelo (Kwéwalkz), there. Joe Duncan's son, Alexander Duncan, became a prominent fixture in the Seaside Indian community, living there well after the decline of the Indian Place and serving as an occasional oral history consultant until his death in Seaside in 1952. ${ }^{61}$ Tribal members Joseph Lane and Jennie Williams Lane also are frequently mentioned as intermittent residents, and later visitors, to the Indian Place community. Joseph Lane, a noted canoe maker, was the son of Chief Washington - a signer of the Clatsops' 1851 treaty - and one of only two of that chief's children to survive into adulthood. His wife, Jennie Lane (née Telzan), was born at around the time of the treaty, to parents of Clatsop, Tillamook, and Nestucca ancestry. ${ }^{62}$ Joseph and Jennie Lane and their children — Louisa, and probably Maria and James - lived in the Indian Place and often appear in photographs of that community from the late nineteenth century.

Despite the community's remarkable successes, there were stresses at the Indian Place that prompted individuals to begin moving away, even as other families continued to arrive. For some, expanding non-Native settlement in the Seaside area and the increasingly disruptive tourist gaze prompted moves to more isolated locations, such as Garibaldi and Bay Center. In turn, the rearranged geographies of tribal settlement introduced new challenges, as displaced and separated families traveled over long and sometimes precarious distances to carry out social and ceremonial activities at customary times. Chief Dunkle and his wife Cleocast ultimately perished in the ocean in 1880 , while trying to paddle from the Indian Place to visit their children Joe Duncan and Mary Duncan Angelo, who had recently relocated to tribal settlements in Tillamook County - the former having just acquired an "Indian Homestead" near Nehalem under the 1887 Dawes Act. As their great-grandson Joe Scovell recalled:

I remember hearing about when my grandmother's parents died. Mary Angelo - and her brother Joe Duncan had moved down to Nehalem. ... They were originally from [the Indian Place village] up in Seaside, but they had moved to Nehalem. And their parents still lived there in Seaside. Their parents decided to come see them.... They left Seaside by canoe. I guess they paddled down the coast, down around Neakahnie Mountain and that area. . . They were going to Nehalem. But they didn't make it. They drowned on the trip between Seaside and Nehalem. Both parents died ... apparently the canoe was overturned in the ocean. ${ }^{63}$ 
In a single, tragic accident, the Indian Place community lost both a leader and a living linkage between the Seaside and the Nehalemarea tribal communities.

The deaths of some of the village's prominent headmen, including Dunkle, prompted relocation to other tribal communities, further undermining the integrity of the Indian Place. So, too, after Kotata's death in 1883, his wife and daughters moved to the Garibaldi community. His daughter Grace and

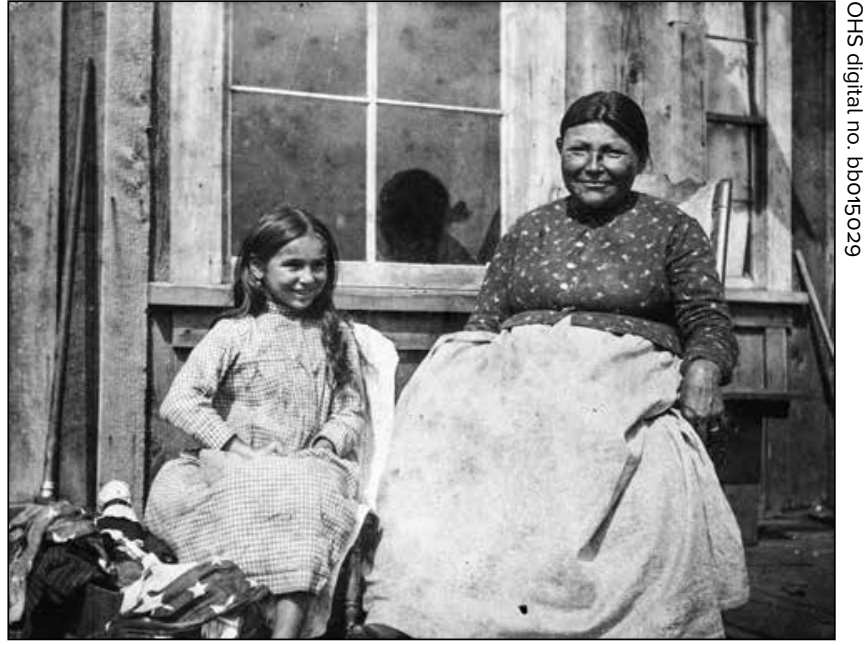

JENNIE LANE and her daughter are pictured here at their Indian Place home. Even after moving away to Willapa Bay in Washington, the Lane (later Williams) family continued to reside intermittently in the Seaside community through its later years and visited there when traveling to Oregon for social and subsistence purposes well into the early twentieth century. her husband, Nehalem headman Joe Swahaw, were prominent figures in that community into the early decades of the twentieth century. Meanwhile, some portion of Kotata's descendants moved to Bay Center, joining the Chinooks and displaced Clatsops there. ${ }^{64}$ Likewise, following Joseph Lane's death in 1894, Jennie Telzan Lane moved to Bay Center to join family in that community and ultimately remarried there. Her family later became prominent in the tribal communities in both Bay Center (Chinook) and Tokeland (Shoalwater Bay), on Washington's Willapa Bay. Other families would leave in the decades to follow. Young families, in particular, left in search of work or of places less overrun by non-Native settlement, often moving multiple times. Those moving north to join the Chinook community in Bay Center followed pathways of earlier migrations - some of these families becoming, in turn, enrolled within the inclusive Quinault Indian Nation. Others moved south, to Garibaldi in particular. A few of these families eventually joined relatives on the Grand Ronde or Siletz reservations, while a sizeable portion of the Garibaldi community - like many of their Bay Center relations - remained formally unaffiliated with a reservation-based tribe.

Thus, by the first decade of the twentieth century, Seaside's Indian population of men and young people dwindled. Observers increasingly characterized the community as an enclave of old women, still keeping traditions such as 


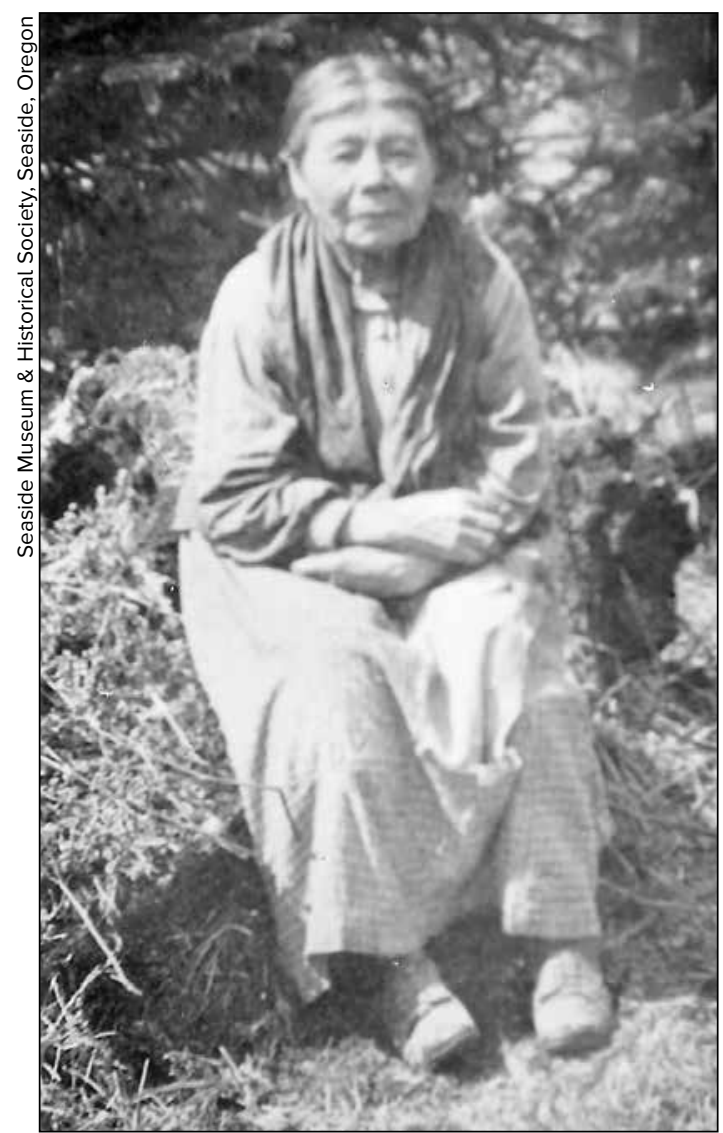

NANCY GERVAIS, or Nish-slush, was daughter of the last Tillamook chief to preside over Nehalem Bay's villages. With her children and husband Ed Gervais - a man of Clatsop and French-Canadian parents - she often worked for Ben Holladay's resort, the Seaside House, gathering food and firewood, and telling tribal stories to guests. When not living in Seaside, the family occupied the former village located in what is today Cannon Beach. basket-making, despite considerable age and inability to gather sufficient food for themselves. At least one non-Native farming family living just east of Seaside was reported to provide regular supplies of food to the elderly women of the community - effectively swapping the food-provider role with the Native community that had sustained their settlements just decades before. ${ }^{65}$ Jennie Michel died in 1905 two years after her husband - and was interred in the impromptu burial ground adjacent to the Indian Place where, decades before, residents had reinterred their ancestors' remains. With her passing, the village lost its figurehead and its principal landowner. The Indian Place persisted, but the ownership of the land gradually fell out of tribal control as families departed and non-Natives bought unoccupied lands. The settlement became a shrinking, ethnically distinct enclave within the encroaching urban fabric of Seaside - a stopover visited while fishing or traveling from settlements outside traditional Clatsop territory. Living tribal descendants still recall returning to the houses of relatives at the former village site, surrounded by non-Native homes, into the 1930 s and $1940 s .{ }^{66}$ Despite tribal efforts to demarcate and preserve the tribal burial site, in time the area was sold off for residential lots. Today, much of the village site lies beneath residential Seaside, as does the burial ground, "a massive graveyard now covered over by trees, houses and mobile homes." ${ }^{67}$ Oral tradition, Native and 
non-Native alike, mentions that most of the old home sites and burial cairns were bulldozed to level the ground for vacation home development between the 1950 s and the 2000s. Only a few persist today in secure and undisclosed locations within residential yards. A small park area is maintained near the former location of the Indian Place, in a site reputed to be near Michel's grave. The non-Native community of Seaside has twice erected a memorial at the site, once in the 1950 s and again in the 1980s, the newest memorial reading "Jennie Meschelle (Tsin-is-tum) - 18151905 - one of the last Clatsop Indian Princesses." Clatsop tribal descendants from many modern communities were present at the unveiling of both memorials. Indian Place descendants from both sides of the Columbia sometimes make journeys to visit this and other cultural sites within the largely urbanized coastal town that supplanted Necotat and Neacoxie.

The Indian Place is today only a memory, but its imprint on modern tribal life endures. Emerging from a period of great hardship, the Indian Place community became a key link between an aboriginal past and a modern tribal present. For tribal descendants, such transitional communities were bulwarks and strongholds of tribal persistence, pivot-points of family histories and biographies, and important conduits for tribal cultural knowledge, values, and practices that endure today. Indian Place and its sibling communities - Bay Center and Tillamook Bay's "Squawtown" among them - fostered the reorganization of traditional communities and arguably shaped the biographies and even cultures of those communities in multiple ways. The Indian Place community was also a key geographical locus for cross-cultural exchanges, where Native families navigated new relationships and forged new identities in juxtaposition to their non-Native neighbors. For non-Native visitors - from early tourists to anthropologists - Indian Place and its sibling communities became the principal venues for engagement with tribal people on Oregon's north coast. Gathering traditional basket-makers, canoebuilders, and storytellers, these communities carried forward rich cultural traditions, giving them new relevance and meaning and providing a venue where such traditions and values could persist even as they were being actively suppressed on many Indian reservations of the nineteenth-century Pacific Northwest. We are all the richer for it, as the Nehalem Tillamook Tales, the Neahkahnie Mountain treasure story, the Native accounts of the Lewis and Clark Expedition - all brought into popular discourse by Indian Place residents - have become part of our state's shared lore.

In the end, most of these transitional settlements could not persist. Of those discussed here, only the Bay Center community remains and thrives 
today, while residents of the Indian Place and Garibaldi moved on to other places. The circumstances of the nineteenth- and early-twentieth-century diaspora ensured that they were dispersed widely, weaving the biographies of Indian Place descendants into myriad tribes.

The outcomes of these events persist to this day. Clatsop people endure, but in configurations that are still not of their choosing. Some two centuries after hosting the Lewis and Clark Expedition, Clatsops find themselves in precarious arrangements - hundreds of individuals, including many Indian Place descendants, seek federal tribal acknowledgement and are denied that important legal distinction. The events outlined in this article hint at the foundations and scale of the problem. The Chinook Indian Nation, still based in Bay Center and arguably home to the largest single concentration of Clatsop descendants, has had its federal acknowledgement denied - sometimes hindered because of the unique history of their Clatsop membership. Even President William Clinton's 2001 executive order briefly granting the Chinook federal status specifically denied that status to their exclusively Clatsop membership, citing the effects of dislocation. The order specifically noted the historically late addition of many Clatsops - Indian Place descendants among them - to the Bay Center community and the fact that Chinook Indian Nation Clatsops had officially lost their status in their state of origin, under the Western Oregon Indian Termination Act. Because of these facts, the Clinton administration supported Chinook restoration but asserted that "those members of the petitioning group [Chinook] whose Indian descent is exclusively from the historical Clatsop Tribe cannot receive federal services because of their status as Indians."68 Simultaneously, critics have sometimes derided descendants of the those Clatsop families that took refuge with Nehalem-Tillamook following their nineteenth-century dislocation - a group including many Seaside Indian Place descendants - as an inauthentic "mongrel group without historic pedigree," to quote one especially acerbic writer, because they share descent from two distinct ethnolinguistic groups. ${ }^{69}$

Both claims against Indian Place descendants are absolutely scurrilous. Strictly "pure" tribal communities are a fiction of the colonial imagination - a point suggested by the long history of intermarriage and other connections between Clatsop families and those of the Chinook, the Nehalem-Tillamook, and other area tribes. And, throughout the United States, many modern tribes are composites, with enrollments from two or more ancestral communities. But more to the point, if the litmus test for Clatsop authenticity and tribal status is living as a single entity on their ancestral homeland, 
unmixed and immobile, then it is clear that the U.S. government is placing modern Clatsops in an impossible position. Indeed, it was the actions of the U.S. government that triggered the Clatsop diaspora and summarily eliminated the possibility of an enduring and singular Clatsop community within their traditional Oregon homeland. To deny the Clatsops the ability to move beyond their core homeland, to take refuge and integrate with adjacent tribal communities on either side of the Columbia River, would have meant denying them the potential to simply adapt and survive into modern times, and would preclude all modern rights of self-determination. These communities are not inauthentic; they are the understandable outcomes of profound nineteenth-century transitions, just as they are a testament to the grit and endurance of tribal people. Critics might raise other objections to formal tribal status for individual organizations, but the authenticity of their deeper heritage should not be in dispute.

Even today, as the abandoned Fort Stevens facility rots into oblivion within the boundaries of an unrealized "Clatsop Indian Reservation," the question of who represents the families of Seaside's Indian Place is contested. So many modern tribes and tribal organizations have historical roots within this nineteenth-century refuge, each with its own modern interests and affiliations. Rightfully, common tribal interests should converge in this special place. Yet, forced into a zero-sum game by the federal acknowledgement process, the descendants of Seaside's Indian Place are compelled to present competing claims and contending visions of what is arguably a single, complex history. The federally unrecognized Chinook and Clatsop-Nehalem most publicly claim that history, while other tribes, such as the Grand Ronde, Shoalwater Bay, Quinault, and Siletz also assert connections, reflecting their historical role as homes to particular Clatsop and Nehalem-Tillamook families seeking refuge in the most difficult of times. In some manner, Seaside's Indian Place is part of all their stories. The accounts of how Indian Place residents found homes in various modern tribes suggests that the boundaries between their interests are not sharp; descendant communities represent, in some respects, a vast network of tribal families that has been broken into discrete pieces for the administrative convenience of the U.S. government. While this article takes a neutral position on the legal matter of who speaks for particular Indian Place descendants - many tribes can and do - it seeks to demonstrate that these descendants indeed persist in large numbers, and that their modern grievances have a complex but traceable etiology. Modern descendants of the Indian Place who lack federal recognition deserve a rehearing of their claims in a manner that is unencumbered 
by an awkwardly imposed colonizing logic and more than a little historical amnesia. Perhaps, with humility, a careful review of the historical facts, and a frank discussion of shared interests, all parties might devise a workable solution that ensures tribal status to deserving Indian Place descendants and trammels on the rights of no one.

An essential part of this reassessment must involve thoughtful reflection on the ground truth of Oregon and Washington's non-reservation Native American settlements. These transitional villages and refugee communities defined the nineteenth- and early-twentieth-century Native experience in northwestern Oregon and beyond. Without a better appreciation of that history, one cannot understand how the Native American peoples of the contact period - Clatsops and others - successfully endured into modern times, becoming part of the tribes and tribal organizations of today. Too often, such communities are given short shrift in conventional historical accounts. This account of Seaside's Indian Place is presented as a partial correction of that striking oversight.

\section{NOTES}

This article is dedicated to the memory of Chief Cliff Snider and Chief Joe Scovell - two leaders who worked tirelessly for the wellbeing of Seaside's Indian Place descendants living on either side of the Columbia River. The work presented here benefitted much from their guidance as well as from many constructive conversations with Ray Gardner (Chinook), Diane Collier (Clatsop-Nehalem), Eirik Thorsgard and David Harrelson (Grand Ronde), Robert Kennta (Siletz), Justine James (Quinault), and others. The author also wishes to thank M. Terry Thompson, Steve Mark, Tricia Gates Brown, the late Paul See, Helen Gaston and the staff of the Seaside Museum \& Historical Society, the staff of the National Archives and Records Administration Seattle archive, the staff of Lewis and Clark National Historical Park, the staff of the Oregon Historical Society Museum, the editorial staff of the Oregon
Historical Quarterly, and two anonymous peer reviewers for their contributions to the manuscript. This research was partially supported by a grant from the Oregon Heritage Commission as well as a National Park Service Cooperative Agreement (Cooperative Agreement No. H8W07110001) undertaken through the Pacific Northwest Cooperative Ecosystem Studies Unit.

1. Thomas Connolly, Human Responses to Change in Coastal Geomorphology and Fauna on the Southern Northwest Coast: Archaeological Investigations at Seaside, Oregon, University of Oregon Anthropological Papers 45 (Eugene: 1992).

2. In some cases, transitional communities stabilize and become permanent, while in other cases they are temporary enclaves only. The concept has become important in discussing indigenous peoples' adapta- 
tion during times of rapid demographic and economic change as well as their active resistance to colonial reoccupation of Native lands, resources, discourses, and bodies during these times. See Adam Curle, "Transitional Communities and Social Reconnection," in Uprooting and After... ed. Charles Zwingmann and Maria Pfister-Amende (New York: Springer-Verlag, 1973), 235-40; and Howard Handelman, Struggle in the Andes: Peasant Political Mobilization in Peru (Austin: University of Texas Press, 2004). Pacific Northwest parallels can be seen in such sources as Robert Boyd, People of The Dalles: The Indians of Wascopam Mission (Lincoln: University of Nebraska Press, 1996).

3. Michael Silverstein, "Chinookans of the Lower Columbia," in Handbook of North American Indians, Volume 7: Northwest Coast, ed. Wayne Suttles (Washington, D.C.: Smithsonian, 1990), 533-46.; Verne Ray, "Lower Chinook Ethnographic Notes," University of Washington Publications in Anthropology 7:2 (Seattle: University of Washington, 1938), 39.

4. For descriptions of Clatsop village names and locations, and a wealth of other information on the identities and linkages between these communities, see Silverstein "Chinookans of the Lower Columbia”; Henry Zenk, Yvonne Hajda, and Robert Boyd, "Chinookan Peoples of the Lower Columbia," Oregon Historical Quarterly, 117:1 (Spring 2016): 6-37; David V. Ellis, "Cultural Geography of the Lower Columbia," in Chinookan Peoples of the Lower Columbia, ed. K. Ames, R. Boyd, and T. Johnson (Seattle: University of Washington Press, 2013); Robert J. Suphan, "An Ethnological Report on the Identity and Localization of Certain Native Peoples of Northwestern Oregon," in Oregon Indians I, American Indian Ethnohistory: Indians of the Northwest, ed. David A. Horr (New York: Garland Publishing, 1974), 167-252; John R. Swanton, The Indian Tribes of North America, Bureau of American Ethnology, Bulletin 145 (Washington D.C.: Smithsonian Institution, 1953); Robert Ruby and John Brown, The Chinook Indians: Traders of the Lower Columbia River (Norman: University of Oklahoma Press, 1988); Barry J. Neilson, "The Indians of Oregon:
Geographic Distribution of Linguistic Families," Oregon Historical Quarterly, 28:1 (Spring 1927): 49-61; and Horace S. Lyman, "Indian Names," The Quarterly of the Oregon Historical Society 1:3 (Fall 1900): 316-26.

5. See James P. Ronda, Astoria and Empire (Lincoln: University of Nebraska Press, 1993); Alexander Ross, Adventures of the first settlers on the Oregon or Columbia River, 1810-1813 (Corvallis: Oregon State University Press, 2000); and Rick Rubin, Naked Against the Rain: The People of the Lower Columbia River (Portland: Far Shore Press, 1999).

6. On the complex motives for the move from Astoria to Fort Vancouver, see Douglas Deur, "Empires of the Turning Tide: A History of Lewis and Clark National and State Historical Parks and the Columbia-Pacific Region," National Park Service, Pacific West Social Science Series No. 2016-001 (Seattle: National Park Service, 2016); and Douglas Deur, "An Ethnohistorical Overview of Groups with Ties to Fort Vancouver National Historic Site," National Park Service, Pacific West Social Science Series No. 2012-12 (Seattle: National Park Service, 2012).

7. These insecurities, especially in the wake of the Tonquin incident, permeate a number of narratives from the period. See, for example, Alfred Seton, Astorian Adventure: The Journal of Alfred Seton, 1811-1815 (Bronx, NY: Fordham University Press, 1993); Gabriel Franchère, Narrative of a Voyage to the Northwest Coast of America in the Years, 1811, 1812, 1813, and 1814, ed. and trans. J.V. Huntington (New York: Bedfield, 1854); and Gabriel Franchère, Adventure at Astoria, ed. and trans. Hoyt Franchère (Norman: University of Oklahoma Press, 1967).

8. See, for example, comments by John McLoughlin in "Letter from John McLoughlin to the Governor, Deputy Governor and Committee, Hudson's Bay Company, November 15, 1843," in The Letters of John McLoughlin from Fort Vancouver to the Governor and Committee: Second Series, 1839-44, ed. E.E. Rich (Toronto: The Champlain Society, 1943). On the rudiments of Clatsop displacement during this period, see James P. Ronda, “Coboway's 
Tale: A Story of Power and Places along the Columbia," in Power and Place in the North American West, eds. Richard White and John M. Findlay (Seattle: University of Washington Press, 1999), 3-22.

9. This account was developed from accounts by residents of the Tillamook Bay "Squawtown" community in 1931, recorded by May Mandelbaum Edel, edited and translated in Douglas Deur and M. Terry Thompson, South Wind Traveled in Winter: A Collection of Nehalem-Tillamook Stories, unpublished manuscript in author's possession.

10. John McLoughlin, "Letter from John McLoughlin to the Governor, Deputy Governor and Committee, Honourable Hudson's Bay Company, August 13, 1829," in Letters of Dr. John McLoughlin, Written at Fort Vancouver, 1829-1832, ed. Burt Brown Barker (Portland: Oregon Historical Society, 1948).

11. Ibid.

12. Most sources concur that the disease was malaria, arriving through infected passengers aboard a ship at Fort Vancouver. For accounts of the "fever and ague," see, for example, Francis Norbert and Modeste Demers, Notices and Voyages of the Famed Quebec Mission to the Pacific Northwest: being the correspondence, notices, etc., of Fathers Blanchet and Demers, together with those of Fathers Bolduc and Langlois. Containing much remarkable information on the areas and inhabitants of the Columbia, Walamette, Cowlitz, and Fraser Rivers, Nesqually Bay, Puget Sound, Whidby, and Vancouver Islands, while on their arduous mission to the engages of the Hudson's Bay Company and the pagan natives, 1838 to 1847. With accounts of several voyages around Cape Horn to Valparaiso and to the Sandwich Islands, etc., trans. Carl Landerholm (Portland: Oregon Historical Society, 1956), 18-19. The epidemic is addressed in various historical sources, for example: Ronda, Astoria and Empire; and S.F. Cook, "The Epidemic of 1830-33 in California and Oregon," University of California Publications in American Archaeology and Ethnology 43:3 (1955): 303-326

13. See Robert Boyd, The Coming of the Spirit of Pestilence: Introduced Infectious
Diseases and Population Decline Among Northwest Coast Indians, 1774-1874 (Seattle: University of Washington Press, 1999).

14. Robert Shortess, Letter to Governor Joseph Lane, April 21, 1850, unpublished. correspondence, Oregon Historical Society Research Library, Portland, MSS 2447.

15. In the days immediately before and after, Dart completed and signed additional treaties, outlining similar agreements for the Chinook proper and other Chinookan-speaking bands, the "Nehalem Band of Tillamooks," and others with whom the Clatsop had enduring relationships.

16. U.S. House of Representatives, "1851 Treaty with the Clatsops," in 32d Congress, 1st Session, Confidential Executive Document 46, Washington, D.C. An especially detailed review and critique of the Tansy Point treaties can be seen in the documents pertaining to recent $\mathrm{Chi}$ nook Nation efforts to seek federal tribal status; Stephen Dow Beckham, "Chinook Indian Tribe: Petition for Federal Acknowledgment” (Lake Oswego, Ore.: USA Research, 1987).

17. As Lane noted of the Chinook, Clatsop, and their lower-river kin,"a very large portion of them act as servants or labourers among the whites, and are becoming very useful in this thinly settled country. I therefore do not believe it is the wish of the people here to have the attempt made to remove them to the east side of the Cascade Mountains - their swift destruction would, I think, be the fruits of such an enterprise." United States Office of the Commissioner of Indian Affairs, Letters of the Oregon Superintendency, Washington Superintendency, and Special Files, 1855-1883. National Archives and Records Administration archives, RG 75.5.1. MS 234. (Washington, D.C, n.d.: Roll 607: 688).

18. See Ronda, Coboway's Tale, 111.

19. "Letter from U.S. Secretary of War, C.M. Conrad to President Millard Fillmore, February 24, 1852," in U.S. Senate, 1878, Report from Committee on Claims regarding Petition of James D. Holman, November 14, 1877, 45th Congress, 1st Session, report no. 9:2 (Washington, D.C.: 1878).

20. The legal record of this decision is reviewed in Report from Committee on Claims 
regarding Petition of James D. Holman, November 14, 1877, 45th Congress, 1st Session, Report no. 9 (Washington, D.C.: 1878).

21. Local settler W.W. Raymond was the principal Sub-Indian Agent assigned to Point Adams in the early 1850 s, replacing Robert Shortess. Raymond recommended to his superiors, "moving the agency of this district to Tilamooke," citing what he described as the will of Clatsops and white settlers alike. As Raymond was a settler who owned land adjacent to the villages, a case could be made that he had personal motivations for expediting Clatsop removal. See W.W. Raymond, "Report to the Superintendent of Indian Affairs - Tansey Point," Annual Reports to the Superintendent of Indian Affairs, 1854-55 (Washington D.C.: U.S. Govt. Printing Office, 1855), 505-506.

22. "United States Secretary of War [John B. Floyd], Report of the Secretary of War, 1860," Senate Executive Document No. 1. 36th Congress, 2nd Session, vol. 2, serial 1079 (Washington, D.C: 1860), 428-29.

23. In John Peabody Harrington, "Tillamook Fieldnotes: Vocabulary, Texts, Grammatical Notes, from Bay Center Washington and Siletz Oregon, recorded 1942-43," microfilm reel \#20, John P. Harrington Papers, Alaska/ Northwest Coast (Washington D.C.: Smithsonian Institution, National Anthropological Archives, n.d.): 386.

24. Douglas Deur, Community, Place and Persistence: An Introduction to ClatsopNehalem History Since the Time of Lewis and Clark (Salem: Oregon Heritage Commission, 2005), 20-21.

25. Captain George H. Elliot, "Letter of recommendation for Chief Tostom, by George H. Elliot, U.S. Army Corps of Engineers, 1867," unpublished correspondence, Clatsop Indian files, Clatsop County Historical Society, Astoria, Oregon.

26. See Deur, Empires of the Turning Tide; and Deur, Community, Place and Persistence.

27. A.B. Meacham, "Annual Report to the Superintendent of Indian Affairs - Oregon Superintendent's Report," Annual Reports to the Superintendent of Indian Affairs (Washington, D.C.: U.S. Govt. Printing Office, 1871), 297-309.
28. Seaside History Museum, "Warrenton: Pioneer Recollections," unpublished ms. (Seaside: Seaside History Museum, n.d.). For a brief time between the 1860 s and the 1870 s, it appears that the Warrenton community was itself a fleeting "pole" of settlement. See Inez Stafford Hanson, "Life on 'Clatsop,", unpublished ms. (Seaside: Seaside History Museum Library, n.d.), 30-32.

29. A term widely used by the non-Native residents of the region, many tribal members found this place name offensive. Still, some descendants from this community still use the term ironically, or to reclaim and problematize it; alternatively, some descendants refer to the community as the "” or "Garibaldi" settlement, although it was only loosely and sometimes uncomfortably associated with the adjacent non-Native settlements by those names. See Deur, Community Place and Persistence.

30. William Clark's journal entry for December 9, 1805, in Reuben Gold Thwaites, ed., Original Journals of the Lewis and Clark Expedition, 1804-1806, vol. 3 (New York: Dodd, Mead \& Co., 1903), 274. The accompanying expedition maps depict the village as consisting of four houses. See also Clark's account in Gary Moulton, ed., The Journals of the Lewis \& Clark Expedition, Volume 6: November 2, 1805-March 22, 1806 (Lincoln: University of Nebraska Press) , 118-19.

31. Daniel Lee and Joseph H. Frost, Ten Years in Oregon (New York: J. Collard, 1844), 275.

32. Harrington, Tillamook Fieldnotes. Melville and Elizabeth Derr Jacobs's tribal interviewees suggested similar Clatsop and Nehalem-Tillamook gatherings and collaborations for salmon fishing, berry picking, and other pursuits in the area. See Melville Jacobs, "Ethnographic Notes: Field Notebooks, Folklore, and Ethnography Based on Three Months' Fieldwork among the Tillamook Salish, Garibaldi Oregon," Melville Jacobs Collection, University of Washington Libraries Special Collections (Seattle, n.d.), folders 106: 2, 7, 8.

33. Preston W. Gillette, "Journals of Preston W. Gillette," unpublished journals (Astoria: Clatsop County Historical Museum, n.d.). 
34. See for example, Beckham, Chinook Indian Tribe; Ruby and Brown, The Chinook Indians; Ray, Lower Chinook Ethnographic Notes; Sauter and Johnston, Tillamook Indians of the Oregon Coast (Portland: Binfords and Mort, 1974), 173; Deur, Community, Place and Persistence, 55-63; and Douglas Deur and M. Terry Thompson, "South Wind's Journeys: A Tillamook Epic," in Salish Myths and Legends: One People's Stories, eds. M.T. Thompson and S.M. Edesdal (Lincoln: University of Nebraska Press, 2008), 4-5.

35. Jennie Michel (Tsin-is-tum), "Recollection of Tsinis-tum (Jennie Michel)," The Quarterly of the Oregon Historical Society 1 (1900): 22-23.

36. Specifically, "the individuals of the said tribe shall be at liberty to occupy, as formerly, their fishing grounds at the mouth of Neacoxsa Creek, whenever they wish to do so for the purpose of fishing, and it is further agreed that the individuals of said tribe shall be allowed to pass freely along the beach from and to their reservation between their fishing grounds and Point Adams." U.S. House of Representatives, 1851 Treaty with the Clatsops.

37. Lee and Frost, Ten Years in Oregon, 275. Various sources provide additional context on missionary use during this period, such as Oregon Pioneer Association, Transactions of the Fifteenth Annual Reunion of the Oregon Pioneer Association for 1887 , transactions volume 15 (Portland: Geo. H. Himes, 1887), 86.

38. Harold Gill, "Letter and maps, from Harold Gill, Chairman of J.K. Gill Company to Burnby Bell, Astoria Oregon, May 1, 1961," unpublished correspondence (Astoria: Lewis and Clark National Historical Park Library and Archive, 1961).

39. Franz Boas, "Chinook Texts," Bureau of American Ethnology, Bulletin 20 (Washington, D.C.: Smithsonian Institution, 1894), 5.

40. See Gillette, Journals of Preston W. Gillette.

41. Paul See, interview with Douglas Deur, September 2004; notes in author's possession.

42. Paul See, ibid; Hanson, Life on Clatsop.
43. Pauline Jorgenson, "The Clatsops," unpublished ms. (Seaside: Seaside History Museum, 1906).

44. Hanson, Life on Clatsop, 36.

45. A long, diffuse correspondence within and between the individual agencies and subagencies addresses the confounding matter of responsibility for off-reservation Indians in this area. The agencies made efforts to establish a roll or census of these Indians to assess their number, needs, and affiliation with federally recognized reservation and treaty tribes. Some portion of the outcomes can be seen in Charles McChesney, Rolls of Certain Indian Tribes in Oregon and Washington (Fairfield, WA: Ye Galleon Press, 1969). On Quinault Indian Agents sometimes venturing into these Oregon communities, see Deur, Community, Place and Persistence, 112-14.

46. Jim Brougher, "The Brougher House," Unpublished ms. (Seaside: Seaside History Museum Library, n.d.).

47. Lewis A. McArthur, Oregon Geographic Names 6th ed. (Portland: Oregon Historical Society Press, 1992), 750-51.

48. Hanson, Life on Clatsop, 31.

49. Ibid.

50. Jennie Michel, in L.B. Cox, "Report of the Committee of the Oregon Historical Society which investigated and accepted identification of the sites of Fort Clatsop and the Salt Cairn," in Proceedings of the Oregon Historical Society, Annual Reports, 1899-1905 (Portland: Oregon Historical Society, 1900), Appendix A: 17.

51. Lee and Frost, Ten Years in Oregon, 286.

52. Gill, "Letter and Maps."

53. In these transitional communities, the use of surnames and adoption of the surnames of male spouses was largely unprecedented. In reservation communities, civil authorities promoted Euro-American naming conventions, but in the relatively autonomous setting of the Indian Place, residents only gradually adopted such conventions through the late nineteenth and early twentieth centuries. Jennie Michel used the name Tsin-is-tum earlier in life, and during her time at the Indian Place she was known simply as "Jennie." After marrying her second 
husband, Michel Martineau, she also went by "Jennie Michel," or "Jennie Martineau" depending on the context - Jennie Michel arguably being the most common.

54. In 1884, for example, deed records indicate that Michel gave or sold a parcel to Julia Marshall, a Clatsop woman and cousin to the Adams sisters (Emma, Jane, and Elizabeth), who were the most enduring members of the Garibaldi settlement. In 1887, Michel deeded a lot to Kate Telzan John, the sister of Jennie Williams Lane, and her Chinook husband by the name of Tommy. Both tracts reverted back to Michel as these people died or moved away. Hanson, Life on Clatsop, 38; Tillamook Pioneer Museum, "Adams Family," unpublished genealogical files (Tillamook: Tillamook Pioneer Museum: n.d.); Deur, Community Place and Persistence.

55. Hanson, Life on Clatsop, 38.

56. "Last of the Clatsops Dies," The Morning Oregonian, February 21, 1905: 8.

57. Michel, Recollection of Tsinis-tum. See also Cox, Report of the Committee of the Oregon Historical Society, Appendix A: 16-17.

58. See Gillette, Journals of Preston W. Gillette; and Deur, Community, Place and Persistence.

59. Mary Gerritse, "Gerritse family, interview transcription," unpublished manuscript (Seaside History Museum, n.d.); Ruby El Hult, Lost Mines and Treasures of the Pacific Northwest (Portland: Binfords and Mort, 1957), 1-42.

6o. Pearson was the principal informant for Elizabeth Derr Jacobs, NehalemTillamook Tales (Corvallis: Oregon State University Press, 1990); and Elizabeth Derr Jacobs, The Nehalem Tillamook: An Ethnography, ed. William Seaburg (Corvallis: Oregon State University Press, 2003). Eilzabeth Derr Jacobs, Melville Jacobs, and May Mandelbaum Edel wrote almost all of the foundational works on Tillamook language and culture, based principally on Pearson's accounts. Pearson's work continues to be mined by later generations of researchers for additional insights; see Deur and Thompson, South Wind's Journeys.

61. The most detailed interviews conducted with Duncan were carried out under Cecile
Adams, working as part of the 1930 W Works Progress Administration Writer's Project, but were never published. Deur, Community, Place and Persistence, 3, 40-41.

62. McChesney, Rolls of Certain Indian Tribes in Oregon and Washington, 69-70.

63. Joe Scovell, interview with Douglas Deur, October 2004, notes in author's possession.

64. Biographical details are recoverable from a variety of sources, including McChesney, Rolls of Certain Indian Tribes in Oregon and Washington; Liisa Penner, "Native Americans, Clatsops," unpublished file folio (Astoria: Clatsop County Historical Society and Clatsop County Genealogical Society, n.d.); William Seaburg, Editor's Introduction, in Jacobs, The Nehalem Tillamook, 47-52; Deur, Community, Place and Persistence, 20-52; Ray, Lower Chinook Ethnographic Notes; and Beckham, Chinook Indian Tribe.

65. Jack Fosmark, "References to Clatsop Indians in Seaside, Oregon," unpublished ms. (Seaside: Seaside History Museum Library, n.d.). The thin available record, including Fosmark's unpublished notes and manuscripts, suggests that this included the family of Joel Henry Minier, an early Seaside settler who owned a farm and dairy just east of the Necanicum estuary at the beginning of the twentieth century. This family had a history of exceptional relationships with $\mathrm{Na}$ tive Americans generally. See documents in "Minier, Abraham Townsend," unpublished Oregon pioneer biography files, Oregon Historical Society Research Library, Portland.

66. Deur, Community, Place and Persistence, 69-71.

67. Penner, "Native Americans, Clatsops."

68. "Final Determination to Acknowledge the Chinook Indian Tribe/Chinook Nation (Formerly: Chinook Indian Tribe, Inc.): Notice of Final Determination," 66 Federal Register 6 (January 9, 2001), p. 1694.

69. Robert H. Ruby to Editor, Seattle PostIntelligencer, April 10, 2004. Correspondence in the archive of USDI National Park Service, Lewis and Clark National Historical Park, Warrenton, Oregon. 